Check for updates

Cite this: Phys. Chem. Chem. Phys., 2020, 22, 17275

Received 30th May 2020, Accepted 7th July 2020

DOI: 10.1039/d0cp02919j

rsc.li/pccp

\title{
Spectroscopic identification of fragment ions of DNA/RNA building blocks: the case of pyrimidine $\dagger$
}

\begin{abstract}
Kuntal Chatterjee (D) and Otto Dopfer (D) *
Pyrimidine (Pym, 1,3-diazine, 1,3-diazabenzene) is an important $\mathrm{N}$-heterocyclic building block of nucleobases. Understanding the structures of its fragment and precursor ions provides insight into its prebiotic and abiotic synthetic route. The long-standing controversial debate about the structures of the primary fragment ions of the Pym ${ }^{+}$cation $\left(\mathrm{C}_{4} \mathrm{H}_{4} \mathrm{~N}_{2}{ }^{+}, \mathrm{m} / \mathrm{z}\right.$ 80) resulting from loss of $\mathrm{HCN}, \mathrm{C}_{3} \mathrm{H}_{3} \mathrm{~N}^{+}$ $(\mathrm{m} / \mathrm{z} 53)$, is closed herein with the aid of a combined approach utilizing infrared photodissociation (IRPD) spectroscopy in the $\mathrm{CH}$ and $\mathrm{NH}$ stretch ranges $\left(\nu_{\mathrm{CH} / \mathrm{NH}}\right)$ and density functional theory (DFT) calculations. IRPD spectra of cold $\mathrm{Ar} / \mathrm{N}_{2}$-tagged fragment ions reveal that the $\mathrm{C}_{3} \mathrm{H}_{3} \mathrm{~N}^{+}$population is dominated by cis-/trans- $\mathrm{HCCHNCH}^{+}$ions ( 90\%) along with a minor contribution of the most stable $\mathrm{H}_{2} \mathrm{CCCNH}^{+}$and cis-/trans- $\mathrm{HCCHCNH}^{+}$isomers ( $\left.\sim 10 \%\right)$. We also spectroscopically confirm that the secondary fragment resulting from further loss of $\mathrm{HCN}, \mathrm{C}_{2} \mathrm{H}_{2}{ }^{+}(\mathrm{m} / \mathrm{z} 26)$, is the acetylene cation $\left(\mathrm{HCCH}^{+}\right)$. The spectroscopic characterization of the identified $\mathrm{C}_{3} \mathrm{H}_{3} \mathrm{~N}^{+}$isomers and their hydrogen-bonded dimers with $\mathrm{Ar}$ and $\mathrm{N}_{2}$ provides insight into the acidity of their $\mathrm{CH}$ and $\mathrm{NH}$ groups. Finally, the vibrational properties of Pym ${ }^{+}$in the $3 \mu \mathrm{m}$ range are probed by IRPD of Pym $^{+}-\left(\mathrm{N}_{2}\right)_{1-2}$ clusters, which shows a high $\pi$-binding affinity of $\mathrm{Pym}^{+}$toward a nonpolar hydrophobic ligand. Its $\nu_{\mathrm{CH}}$ spectrum confirms the different acidity of the three nonequivalent $\mathrm{CH}$ groups.
\end{abstract}

\section{Introduction}

Nucleobases, the molecular building blocks of the fundamental genetic materials DNA and RNA, are primarily composed of two different aromatic nitrogen heterocycles (N-heterocylces), namely pyrimidine (1,3-diazine, 1,3-diazabenzene, Pym, $\mathrm{C}_{4} \mathrm{H}_{4} \mathrm{~N}_{2}$ ) and purine. The pyrimidine nucleobases are uracil, thymine, and cytosine, whereas adenine and guanine are purine bases. The ubiquity of these few selected nucleobases involved in the evolution of life on Earth shows a clear example of restricted natural selectivity upon which life as we know it developed. ${ }^{1-4}$ Apart from nucleobases, Pym is also a building block of other natural and artificial bioactive molecules (e.g., vitamin $\mathrm{B}_{1}$ or thiamine, barbituric acid). ${ }^{5,6}$

The early Earth was exposed to strong solar irradiation (particularly UV), because of the absence of the protecting ozone layer. Therefore, only photochemically stable molecules survived during that time. Interestingly, pyridine and diazine molecules with their short first excited state $\left(\mathrm{n} \pi^{*}\right)$ lifetimes fall in such a photochemically robust category. ${ }^{3,7-12}$ The canonical DNA/RNA bases comprised of these N-heterocycles also exhibit such short-lived excited states because of ultrafast internal

Institut für Optik und Atomare Physik, TU Berlin, Hardenbergstr. 36, 10623 Berlin, Germany.E-mail: dopfer@physik.tu-berlin.de

$\dagger$ Electronic supplementary information (ESI) available. See DOI: 10.1039/d0cp02919j conversion to the ground electronic state, and their high photostability may explain their abundance in genetic materials. ${ }^{3,4,13-19}$

Because of their abundance on Earth, these nucleobases and their building blocks such as Pym have been intensively searched for in extraterrestrial media to understand their possible delivery to Earth. ${ }^{20-23}$ Although such investigations have failed so far, the presence of these aromatic N-heterocycles in the interstellar medium has received widespread acceptance. ${ }^{24-32}$ For example, the $6.2 \mu \mathrm{m}$ feature in the unidentified infrared emission spectrum was suggested to originate from polycyclic aromatic hydrocarbons with at least one $\mathrm{N}$ atom in the aromatic skeleton. ${ }^{23}$ The detection of Pym- and purine-based compounds in carbonaceous meteorites further strengthens the possibility of the extraterrestrial presence of $\mathrm{N}$-heterocycles. ${ }^{33-36}$ Because of their biological importance, prebiotic synthetic routes for these nucleobases have been well explored. ${ }^{37,38}$ It has been proposed that such $\mathrm{N}$-containing macromolecules may be synthesized through complex reactions between abundant N-bearing species such as $\mathrm{NH}_{3}$ or $\mathrm{HCN}$ and carbonaceous precursors in interstellar ice grains under the influence of UV photons and cosmic ray analogs (e.g., protons and electrons) ${ }^{39-43}$ Recent laboratory experiments under interstellar-like conditions demonstrate the formation of uracil and cytosine upon UV irradiation of $\mathrm{H}_{2} \mathrm{O}$ :Pym and $\mathrm{H}_{2} \mathrm{O}: \mathrm{NH}_{3}: \mathrm{Pym}$ ices, respectively. ${ }^{44,45}$ These experiments triggered theoretical investigations to gain further insight into the involved chemical conversion scheme. ${ }^{46}$ Similar studies of 
$\mathrm{CH}_{3} \mathrm{OH}: \mathrm{Pym}, \mathrm{H}_{2} \mathrm{O}: \mathrm{CH}_{3} \mathrm{OH}: \mathrm{Pym}$, and $\mathrm{CH}_{4}: \mathrm{Pym}$ ices reveal the generation of thymine, along with numerous amino pyrimidines and their hydroxyl derivatives. ${ }^{40}$ Related photon processing of $\mathrm{H}_{2} \mathrm{O}: \mathrm{NH}_{3}$ :purine ices results in the formation of adenine, guanine, and other substituted purine derivatives. ${ }^{41,47}$ Interestingly, apart from photon irradiation of simple $\mathrm{H}_{2} \mathrm{O}$ :Pym ices leading to thymine formation, all other photon processing results in the production of RNA nucleobases and thus supports the hypothesis of RNA being the first type of genetic material used by early life. ${ }^{48}$

The Pym nucleobases inherit certain properties like their geometry and core and valence electronic structure from the parent Pym moiety, ${ }^{49,50}$ which renders this $\mathrm{N}$-heterocycle a subject of demanding attention. Understanding the abiotic origin of such genetic material is of fundamental interest for prebiotic chemistry and astrobiology. Several prudent experimental techniques, such as gas-phase photon or electron ionization (EI) and mass spectrometry, have been employed along with computations to explore abiotic routes of both Pym formation and fragmentation. ${ }^{51-66}$ These studies have established two main fragment ions of the $\mathrm{Pym}^{+}$cation, $\mathrm{C}_{3} \mathrm{H}_{3} \mathrm{~N}^{+}$ ( $m / z 53)$ and $\mathrm{C}_{2} \mathrm{H}_{2}{ }^{+}(\mathrm{m} / \mathrm{z} 26)$, through the elimination of one and two HCN molecules, respectively. ${ }^{55-57,61,64,65}$ Interestingly, there is a long-standing debate about the molecular structure of the $\mathrm{C}_{3} \mathrm{H}_{3} \mathrm{~N}^{+}$fragment. An early mass-spectrometric study using isotope labeling suggested the kinetically favoured $\mathrm{HCCHNCH}^{+}$structure $(4 / 5)$ because this fragmentation channel can eliminate $\mathrm{HCN}$ containing $\mathrm{C} 4$ (e.g., H4C4N3), without further structural arrangement. ${ }^{60}$ Subsequently, the acrylonitrile cation $\left(\mathrm{H}_{2} \mathrm{CCHCN}^{+}, 6\right)$ was considered, ${ }^{56,66}$ which however was later discarded because of the dissimilarity of its collisioninduced dissociation (CID) spectrum and enthalpy of formation $\left(\Delta_{\mathrm{f}} H\right)$ from those of the $\mathrm{C}_{3} \mathrm{H}_{3} \mathrm{~N}^{+}$ion originating from Pym ${ }^{+} .6,58,64$ Instead, the most stable $\mathrm{H}_{2} \mathrm{CCCNH}^{+}$isomer of $\mathrm{C}_{3} \mathrm{H}_{3} \mathrm{~N}^{+}(\mathbf{1})$ with a CCCN backbone was suggested as the major contributing structure of this daughter ion, because it is more stable than 6 and other $\mathrm{C}_{3} \mathrm{H}_{3} \mathrm{~N}^{+}$isomers, such as $\mathrm{HCCCHNH}^{+}(\mathbf{1 1} / \mathbf{1 2})$ and $\mathrm{HCCHCNH}^{+}(2 / 3) .{ }^{64}$ However, the generation of 1 from $\mathrm{Pym}^{+}$demands a large activation barrier, as revealed from a detailed computational study of all feasible $\mathrm{C}_{3} \mathrm{H}_{3} \mathrm{~N}^{+}$isomers. ${ }^{67}$ A photoionization-fragmentation study suggested either 6 or $\mathrm{H}_{2} \mathrm{CNCCH}^{+}$(7). ${ }^{63}$ On the other hand, a theoretical study showed effective radical site formation on the $\mathrm{N}$ atom upon ionization of Pym that disintegrates into 6 or $\mathrm{H}_{2} \mathrm{CCNCH}^{+}$(8) by eliminating $\mathrm{HCN}^{65}$ An electron-ionization mass spectrometric study concluded the kinetically favorable $\mathrm{HCCHNCH}^{+}$isomer $(\mathbf{4} / \mathbf{5})$ to be the most probable $\mathrm{C}_{3} \mathrm{H}_{3} \mathrm{~N}^{+}$structure. ${ }^{51}$ A recent massspectrometric and computational investigation reported the formation of $\mathrm{Pym}^{+}$by the sequential barrierless addition of two $\mathrm{HCN}$ molecules to the acetylene cation $\left(\mathrm{HCCH}^{+}, \mathrm{HC} \equiv \mathrm{CH}^{+}\right)$, and the suggested intermediate $\mathrm{C}_{3} \mathrm{H}_{3} \mathrm{~N}^{+}$ions have again been 4/5. ${ }^{68}$ In the reverse direction, the $\mathrm{C}_{3} \mathrm{H}_{3} \mathrm{~N}^{+}$ion dissociates via HCN elimination into $\mathrm{C}_{2} \mathrm{H}_{2}{ }^{+}(\mathrm{m} / z$ 26) , which was identified as the acetylene cation $\left(\mathrm{HCCH}^{+}\right)$by comparing their $\Delta_{\mathrm{f}} H$ values. ${ }^{51,57,59,69}$ Quantum chemical investigations demonstrate an efficient production scheme of the $\mathrm{HCCH}^{+}$cation from $4 / 5$ by HCN elimination. ${ }^{54,58,61,62,67}$
So far, the identification of the $m / z 53$ and 26 fragment ions of Pym ${ }^{+}$has been solely based on mass spectrometry, thermochemistry, and quantum chemistry. Unambiguous spectroscopic confirmation of the structures suggested for these two important fragment ions of $\mathrm{Pym}^{+}$are lacking. To this end, this work aims at the infrared (IR) spectroscopic identification of these two major $\mathrm{Pym}^{+}$fragments. For this purpose, we employ an EI technique to produce $\mathrm{Pym}^{+}$which dissociates in the source mainly into $\mathrm{C}_{3} \mathrm{H}_{3} \mathrm{~N}^{+}$ and $\mathrm{C}_{2} \mathrm{H}_{2}{ }^{+}$. We generate the $\mathrm{Ar} / \mathrm{N}_{2}$-tagged clusters of both $\mathrm{Pym}^{+}$ and its fragment ions, whose structures are then probed by IR photodissociation (IRPD) spectroscopy. These fingerprint spectra are analyzed with the aid of dispersion-corrected density functional theory (DFT) calculations to unambiguously identify the contributing structural isomers and competing ligand binding sites. This combined spectroscopic/computational approach has previously been applied to various aromatic and nonaromatic cluster ions in our laboratory to unravel their structure and bonding. ${ }^{30-32,70-77}$

\section{Experimental methods}

IRPD spectra of mass-selected Pym $^{+}-\left(\mathrm{N}_{2}\right)_{n}$ clusters $(n=1-2)$ and the $\mathrm{Ar} / \mathrm{N}_{2}$-tagged clusters of $\mathrm{Pym}^{+}$fragments, i.e. $\mathrm{C}_{3} \mathrm{H}_{3} \mathrm{~N}^{+}-\mathrm{L}_{n}$ $\left(n=0, n=1\right.$ for Ar, $n=1-3$ for $\left.\mathrm{N}_{2}\right)$ and $\mathrm{C}_{2} \mathrm{H}_{2}{ }^{+}-\mathrm{L}\left(\mathrm{L}=\mathrm{Ar} / \mathrm{N}_{2}\right)$, are acquired between 2900 and $3600 \mathrm{~cm}^{-1}$ in a tandem quadrupole mass spectrometer coupled to an EI source and an octupole ion guide. ${ }^{78,79}$ Briefly, the investigated ions and their clusters are produced in a pulsed supersonic plasma expansion utilizing electron and chemical ionization close to the nozzle orifice. Electrons are emitted from two tungsten filaments close to the nozzle orifice. The expanding gas mixture is produced by seeding the vapor of Pym (Sigma-Aldrich, >98\%, used without further purification) heated to $333 \mathrm{~K}$ in $\mathrm{N}_{2}$ or Ar carrier gas (10 bar). The desired parent cluster ions are mass-selected in the first quadrupole and irradiated in the adjacent octupole ion guide with a tunable IR laser pulse $\left(\nu_{\mathrm{IR}}\right)$ emitted from an optical parametric oscillator laser pumped by a nanosecond Q-switched Nd:YAG laser operating at $10 \mathrm{~Hz}$. The IR laser pulses are characterized by a bandwidth of $1 \mathrm{~cm}^{-1}$ and energies of 1-5 mJ. Resonant vibrational excitation leads to the elimination of all weakly bound ligands. The $\mathrm{C}_{3} \mathrm{H}_{3} \mathrm{~N}^{+}$monomer spectrum is recorded in the HCN loss channel. The resulting daughter ions are mass-selected by the second quadrupole and monitored with a Daly detector as a function of $\nu_{\mathrm{IR}}$ to derive the IRPD spectrum of the parent cluster. The photofragmentation spectra are linearly normalized for energy fluctuations of the laser pulses recorded with a pyroelectric detector. To obtain the IRPD yield, the background contribution arising from metastable decay (laser-off signal) is subtracted from the laser-on signal by triggering the ion source at twice the laser repetition rate. The observed widths of the vibrational transitions are mainly due to the unresolved rotational structure, lifetime broadening, sequence hot bands involving low-frequency interand intramolecular modes $\left(\nu_{\mathrm{CH} / \mathrm{NH}}+\nu_{\mathrm{x}} \leftarrow \nu_{\mathrm{x}}\right)$, and possible overlapping contributions from various structural isomers. 
Low-energy collision-induced dissociation (CID) spectra at $\sim 10 \mathrm{eV}$ collision energy in the laboratory frame are recorded by introducing $10^{-5}$ mbar $\mathrm{N}_{2}$ into the octopole to confirm the composition of the ions and their clusters. IRPD spectra of $\mathrm{Pym}^{+}-\mathrm{Ar}_{n}$ clusters can not be recorded with this setup because of the mass overlap of $\mathrm{Pym}^{+}$with the much more abundant isobaric $\mathrm{Ar}_{2}$ ion $(\mathrm{m} / \mathrm{z}$ 80). A typical mass spectrum of the EI ion supersonic expansion source using $\mathrm{N}_{2}$ carrier gas is quite similar to the published standard EI spectrum of isolated Pym (apart from signals arising from $\mathrm{N}_{2}$ and $\mathrm{H}_{2} \mathrm{O}$ impurity), ${ }^{80}$ with dominant peaks at $m / z 80\left(\mathrm{Pym}^{+}\right), 53\left(\mathrm{C}_{3} \mathrm{H}_{3} \mathrm{~N}^{+}\right)$, and $28\left(\mathrm{C}_{2} \mathrm{H}_{2}^{+}\right)$, strongly suggesting that that the ionization and fragmentation processes are rather similar under both conditions (Fig. S1 in the ESI $\dagger$ ). This scenario is supported by a previous energy-resolved ionization study of Pym, ${ }^{56}$ which concludes that $\mathrm{Pym}^{+}$cations generated in higher electronic states undergo rapid internal conversion into the lowest electronic state before statistical dissociation occurs on the ground state potential. The CID spectra of mass-selected $\mathrm{Pym}^{+}$and $\mathrm{C}_{3} \mathrm{H}_{3} \mathrm{~N}^{+}$ions show the exclusive loss of HCN (Fig. S2, ESI $\dagger$ ).

\section{Computational methods}

Various structural isomers of the $\mathrm{C}_{3} \mathrm{H}_{3} \mathrm{~N}^{+}$ion and conceivable ligand binding sites of $\mathrm{Ar}$ and $\mathrm{N}_{2}$ to $\mathrm{Pym}^{+}, \mathrm{C}_{3} \mathrm{H}_{3} \mathrm{~N}^{+}$, and $\mathrm{C}_{2} \mathrm{H}_{2}{ }^{+}$ are explored at the B3LYP-D3/aug-cc-pVTZ level of DFT theory to analyze their experimental IR spectra. ${ }^{81}$ This dispersioncorrected functional accounts well for the electrostatic, induction, and dispersion forces of the investigated clusters. ${ }^{30-32,74-77}$ Fully relaxed potential energy surface calculations are performed during the search for stationary points, and their nature as minima or transition states are verified by harmonic frequency analysis. Harmonic intramolecular vibrational frequencies are scaled with 0.96221 , obtained by fitting the $\nu_{\mathrm{CH} / \mathrm{OH}}$ frequencies of Pym and $\mathrm{H}_{2} \mathrm{O}$ to their experimental values in a parallel study of $\mathrm{H}^{+}$Pym- $\left(\mathrm{H}_{2} \mathrm{O}\right)_{n}$. Computed scaled IR stick spectra are convoluted with Gaussian line profiles with $\mathrm{FWHM}=10 \mathrm{~cm}^{-1}$ to facilitate convenient comparison with the experimental spectra. All relative energies $\left(E_{\mathrm{e}}\right)$ and equilibrium dissociation energies $\left(D_{\mathrm{e}}\right)$ are corrected for harmonic zero-point vibrational energy to derive $E_{0}$ and $D_{0}$ values. Gibbs free energies $(G)$ are reported for $T=298.15 \mathrm{~K}$. Cartesian coordinates and energies of all relevant structures are listed in the ESI. $\dagger$ The atomic charge distribution and second-order perturbation energies $\left(E^{(2)}\right)$ of the donor-acceptor orbitals involved in the hydrogen bond (H-bond) interaction are calculated using natural bond orbital (NBO) analysis. ${ }^{82}$ Only doublet electronic states are considered. ${ }^{67}$

\section{Results and discussion}

The IRPD spectra of Pym ${ }^{+}-\left(\mathrm{N}_{2}\right)_{n=1-2}, \mathrm{C}_{3} \mathrm{H}_{3} \mathrm{~N}^{+}, \mathrm{C}_{3} \mathrm{H}_{3} \mathrm{~N}^{+}-\mathrm{L}$, and $\mathrm{C}_{2} \mathrm{H}_{2}{ }^{+} \mathrm{L}\left(\mathrm{L}=\mathrm{Ar} / \mathrm{N}_{2}\right)$ recorded between 2900 and $3550 \mathrm{~cm}^{-1}$ are summarized in Fig. 1. The positions, widths, and vibrational and isomer assignments of the experimental transitions (labeled A-F) are listed in Tables 1-3. The investigated spectral

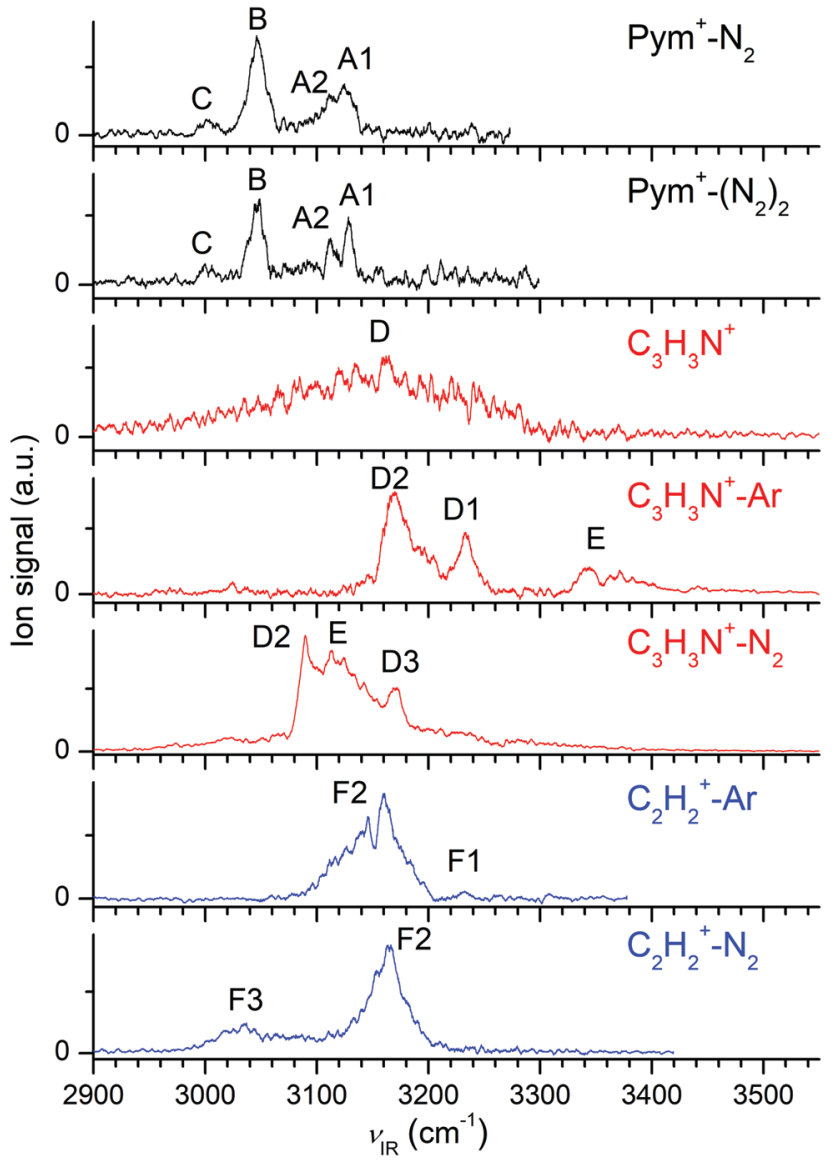

Fig. 1 IRPD spectra of Pym ${ }^{+}-\left(\mathrm{N}_{2}\right)_{n}$ with $n=1-2, \mathrm{C}_{3} \mathrm{H}_{3} \mathrm{~N}^{+}-\mathrm{L}_{n}(n=0-1)$, and $\mathrm{C}_{2} \mathrm{H}_{2}{ }^{+}$- $\mathrm{L}$ clusters $\left(\mathrm{L}=\mathrm{Ar} / \mathrm{N}_{2}\right)$ recorded between 2900 and $3550 \mathrm{~cm}^{-1}$ covering the $\mathrm{CH}$ and $\mathrm{NH}$ stretch range. The positions, widths, and vibrational and isomer assignments of the transitions observed $(A-F)$ are listed in Tables 1-3. The IRPD spectra of the clusters are monitored in the monomer ion fragment channel, while the spectrum of bare $\mathrm{C}_{3} \mathrm{H}_{3} \mathrm{~N}^{+}$is recorded in the $\mathrm{HCN}$ loss channel.

range covering the $\mathrm{NH}$ and $\mathrm{CH}$ stretch fundamentals $\left(\nu_{\mathrm{NH} / \mathrm{CH}}\right)$ is diagnostic for identifying the contributing isomers along with their competing ligand binding sites. The free and bound $\mathrm{XH}$ stretch modes $(\mathrm{X}=\mathrm{N} / \mathrm{C})$ are classified as $\nu_{\mathrm{XH}}^{\mathrm{f}}$ and $\nu_{\mathrm{XH}}^{\mathrm{b}}$, respectively. The IRPD spectra of $\mathrm{Pym}^{+}-\left(\mathrm{N}_{2}\right)_{n=1-2}$ reveal the vibrational properties of $\mathrm{Pym}^{+}$in the $3 \mu \mathrm{m}$ range, yielding all $\nu_{\mathrm{CH}}$ frequencies of Pym ${ }^{+}$. The broad IR spectrum of the $\mathrm{C}_{3} \mathrm{H}_{3} \mathrm{~N}^{+}$ monomer becomes narrower after tagging with an inert gas $\left(\mathrm{Ar} / \mathrm{N}_{2}\right)$ through the substantial reduction of both the internal energy of the ions and the lowest dissociation threshold. At first, we discuss the structural, vibrational, and electronic parameters of Pym, $\mathrm{Pym}^{+}$, and $\mathrm{Pym}^{+}-\left(\mathrm{N}_{2}\right)_{n}$ and compare the effects of ionization and cluster formation. Subsequently, similar analyses are performed for $\mathrm{C}_{3} \mathrm{H}_{3} \mathrm{~N}^{+}$and $\mathrm{C}_{2} \mathrm{H}_{2}{ }^{+}$and their Ar and $\mathrm{N}_{2}$ clusters.

\subsection{Pym, Pym ${ }^{+}$, and Pym $^{+}-\left(\mathrm{N}_{2}\right)_{n=1-2}$ clusters}

Pym has a planar equilibrium structure with $C_{2 \mathrm{v}}$ symmetry in its ${ }^{1} \mathrm{~A}_{1}$ ground electronic state (Fig. 2), as revealed from electron diffraction and microwave, IR, and Raman spectroscopy. ${ }^{9,83-88}$ 
Table 1 Positions, widths (fwhm in parentheses), and suggested vibrational and isomer assignments of the transitions observed in the IRPD spectra of Pym $^{+}-\left(N_{2}\right)_{1-2}$ clusters (Fig. 2) compared to frequencies calculated at the B3LYP-D3/aug-cc-pVTZ level. All values are given in $\mathrm{cm}^{-1}$. For comparison, spectral data of $\mathrm{Pym}^{(+)}$are provided

\begin{tabular}{|c|c|c|c|c|}
\hline & Exp. $\left(\mathrm{cm}^{-1}\right)$ & Calc. $^{a}\left(\mathrm{~cm}^{-1}\right)$ & Vibration & Isomer \\
\hline Pym & $\begin{array}{l}3074^{b} \\
3050^{b} \\
3039^{b} \\
3002^{b}\end{array}$ & $\begin{array}{l}3076\left(9, a_{1}\right) \\
3043\left(13, a_{1}\right) \\
3032\left(18, b_{2}\right) \\
3029\left(14, a_{1}\right)\end{array}$ & $\begin{array}{l}\nu_{\mathrm{C} 5 \mathrm{H}}\left(\nu_{13}\right) \\
\nu_{\mathrm{C} 2 \mathrm{H}}\left(\nu_{20 \mathrm{a}}\right) \\
\nu_{\mathrm{C} 4 \mathrm{H} / \mathrm{C} 6 \mathrm{H}}(\mathrm{as})\left(\nu_{\mathrm{7b}}\right) \\
\nu_{\mathrm{C} 4 \mathrm{H} / \mathrm{C} 6 \mathrm{H}}(\mathrm{s})\left(\nu_{2}\right)\end{array}$ & $\begin{array}{l}\text { Pym } \\
\text { Pym } \\
\text { Pym } \\
\text { Pym }\end{array}$ \\
\hline Pym $^{+}$ & $\begin{array}{l}3124 \pm 2^{c} \\
3112 \pm 2^{c} \\
3045 \pm 2^{c} \\
3045 \pm 2^{c}\end{array}$ & $\begin{array}{l}3117\left(20, a_{1}\right) \\
3103\left(15, a_{1}\right) \\
3031\left(49, b_{2}\right) \\
3031\left(13, a_{1}\right)\end{array}$ & $\begin{array}{l}\nu_{\mathrm{C} 2 \mathrm{H}}\left(\nu_{13}\right) \\
\nu_{\mathrm{C} 5 \mathrm{H}}\left(\nu_{20 \mathrm{a}}\right) \\
\nu_{\mathrm{C} 4 \mathrm{H} / \mathrm{C} 6 \mathrm{H}}(\mathrm{as})\left(\nu_{7 \mathrm{~b}}\right) \\
\nu_{\mathrm{C} 4 \mathrm{H} / \mathrm{C} 6 \mathrm{H}}(\mathrm{s})\left(\nu_{2}\right)\end{array}$ & $\begin{array}{l}\text { Pym }^{+} \\
\text {Pym }^{+} \\
\text {Pym }^{+} \\
\text {Pym }^{+}\end{array}$ \\
\hline $\mathrm{Pym}^{+}-\mathrm{N}_{2}$ & $\begin{array}{l}\text { A1 } 3125(20) \\
\text { A2 } 3111(16) \\
\text { B } 3046(15) \\
\text { C } 3001(20)\end{array}$ & $\begin{array}{l}3119\left(18, a^{\prime}\right), 3117\left(18, a^{\prime}\right) \\
3103\left(14, a^{\prime}\right), 3103\left(15, a^{\prime}\right) \\
3032\left(45, a^{\prime \prime}\right), 3032\left(29, a^{\prime}\right) \\
3032\left(12, a^{\prime}\right) \\
3008\left(200, a^{\prime}\right)\end{array}$ & $\begin{array}{l}\nu_{\mathrm{C} 2 \mathrm{H}}^{\mathrm{f}} \\
\nu_{\mathrm{C} 5 \mathrm{H}}^{\mathrm{f}} \\
\nu_{\mathrm{C} 4 \mathrm{H} / \mathrm{C} 6 \mathrm{H}(\mathrm{as})}^{\mathrm{f}}, \nu_{\mathrm{C} 6 \mathrm{H}}^{\mathrm{f}} \\
\nu_{\mathrm{C} 4 \mathrm{H} / \mathrm{C} 6 \mathrm{H}(\mathrm{s})}^{\mathrm{f}} \\
\nu_{\mathrm{C} 4 \mathrm{H}}^{\mathrm{b}}\end{array}$ & $\begin{array}{l}\text { Pym }^{+}-\mathrm{N}_{2}(\pi), \mathrm{Pym}^{+}-\mathrm{N}_{2}(\mathrm{C} 4) \\
\text { Pym }^{+}-\mathrm{N}_{2}(\pi), \text { Pym }^{+}-\mathrm{N}_{2}(\mathrm{C} 4) \\
\text { Pym }^{+}-\mathrm{N}_{2}(\pi), \text { Pym }^{+}-\mathrm{N}_{2}(\mathrm{C} 4) \\
\text { Pym }^{+}-\mathrm{N}_{2}(\pi) \\
\text { Pym }^{+}-\mathrm{N}_{2}(\mathrm{C} 4)\end{array}$ \\
\hline $\operatorname{Pym}^{+}-\left(\mathrm{N}_{2}\right)_{2}$ & $\begin{array}{l}\text { A1 } 3128(8) \\
\text { A2 } 3112(10) \\
\text { B } 3048(16) \\
\text { C } 3003(14)\end{array}$ & $\begin{array}{l}3120\left(17, a_{1}\right), 3119(17) \\
3103\left(13, a_{1}\right), 3103(14) \\
3033\left(41, b_{2}\right), 3033(27) \\
3033\left(11, a_{1}\right) \\
3011(187) \\
3011\left(79, a_{1}\right), 3010\left(301, b_{2}\right)\end{array}$ & $\begin{array}{l}\nu_{\mathrm{C} 2 \mathrm{H}}^{\mathrm{f}} \\
\nu_{\mathrm{C} 5 \mathrm{H}}^{\mathrm{f}} \\
\nu_{\mathrm{C} 4 \mathrm{H} / \mathrm{C} 6 \mathrm{H}(\mathrm{as})}^{\mathrm{f}}, \nu_{\mathrm{C} 6 \mathrm{H}}^{\mathrm{f}} \\
\nu_{\mathrm{C} 4 \mathrm{H} / \mathrm{C} 6 \mathrm{H}(\mathrm{s})}^{\mathrm{f}} \\
\nu_{\mathrm{C} 4 \mathrm{H}}^{\mathrm{b}} \\
\nu_{\mathrm{C} 4 \mathrm{H} / \mathrm{C} 6 \mathrm{H}(\mathrm{s} / \mathrm{a})}^{\mathrm{b}}\end{array}$ & $\begin{array}{l}\operatorname{Pym}^{+}-\left(\mathrm{N}_{2}\right)_{2}(\pi / \pi), \text { Pym }^{+}-\mathrm{N}_{2}(\mathrm{C} 4 / \pi) \\
\text { Pym }^{+}-\left(\mathrm{N}_{2}\right)_{2}(\pi / \pi), \text { Pym }^{+}-\mathrm{N}_{2}(\mathrm{C} 4 / \pi) \\
\text { Pym }^{+}-\left(\mathrm{N}_{2}\right)_{2}(\pi / \pi), \text { Pym }^{+}-\mathrm{N}_{2}(\mathrm{C} 4 / \pi) \\
\text { Pym }^{+}-\left(\mathrm{N}_{2}\right)_{2}(\pi / \pi) \\
\text { Pym }^{+}-\mathrm{N}_{2}(\mathrm{C} 4 / \pi) \\
\text { Pym }^{+}-\mathrm{N}_{2}(\mathrm{C} 4 / \mathrm{C} 6)\end{array}$ \\
\hline
\end{tabular}

${ }^{a}$ Vibrational symmetry species and IR intensities (in $\mathrm{km} \mathrm{mol}^{-1}$ ) are listed in parentheses. ${ }^{b}$ Ref. 9, 88 and $91 .{ }^{c}$ Extrapolated from the Pym ${ }^{+}-\left(\mathrm{N}_{2}\right)_{n}$ data.

Our calculated geometric and vibrational parameters agree well with available experimental data, ${ }^{83-87}$ demonstrating the reliability of our chosen computational approach (Table 1 and Table S1, ESI $\dagger$ ). Information about the electronic and vibrational properties of the ground electronic state of the $\mathrm{Pym}^{+}$ cation comes from photoelectron and photoionisation spectroscopy, and calculations. ${ }^{49,59,89-93}$ Ionization of Pym into its ${ }^{2} \mathrm{~B}_{2}$ cation ground electronic state $\left(C_{2 \mathrm{v}}\right)$ occurs by removal of an electron from the highest occupied in-plane $b_{2}$ orbital of Pym, which is a linear combination of the nonbonding lone pair orbitals of the $\mathrm{N}$ atoms and the bonding $\sigma$ orbitals of the aromatic skeleton (Fig. S3, ESI $\dagger$ ). In line with the shape of this HOMO, the N1-C2 (N3-C2) and N1-C6 (N3-C4) bonds elongate (by 11 and $18 \mathrm{~mA}$ ), while the $\mathrm{C} 4-\mathrm{C} 5$ (C5-C6) bonds contract (by $6 \mathrm{~mA}$ ). As expected, in contrast to the significant deformation of the heavy atom skeleton, the $\mathrm{C}-\mathrm{H}$ bonds are much less effected by ionization, with changes of $-1,+2$, and $-4 \mathrm{~m} \AA$ for $\mathrm{C} 5-\mathrm{H}, \mathrm{C} 4 / 6-\mathrm{H}$, and $\mathrm{C} 2-\mathrm{H}$, respectively. As a result of these modest geometry changes, the previous photoionization spectra do not reveal any experimental information about the $\nu_{\mathrm{CH}}$ frequencies of $\mathrm{Pym}^{+}$due to vanishing Franck-Condon factors. ${ }^{91-93}$ Our computations predict that ionization slightly contracts the $\mathrm{C}-\mathrm{H}$ bonds leading to an increase in average $\nu_{\mathrm{CH}}$ frequency $\left(\Delta \nu_{\mathrm{CH}}=+74,+27,-1,+2 \mathrm{~cm}^{-1}\right.$ for $\nu_{\mathrm{C} 2 \mathrm{H}}, \nu_{\mathrm{C} 5 \mathrm{H}}$, $\left.\nu_{\mathrm{C} 4 \mathrm{H} / \mathrm{C} 6 \mathrm{H}}(\mathrm{a}), \nu_{\mathrm{C} 4 \mathrm{H} / \mathrm{C} 6 \mathrm{H}}(\mathrm{s})\right)$ and a slight increase in IR intensity (Fig. 3). The predicted adiabatic ionization energy is comparable to the previously measured value (IE $=73568 v s .75261 \mathrm{~cm}^{-1}$ ), and also our computed frequencies agree well with available measured ones (Table S2, ESI $\dagger$ ). ${ }^{91-93}$ The positive charge resides mainly on the peripheral hydrogens (Fig. S4, ESI $\dagger$ ). All efforts to record an IRPD spectrum of bare $\mathrm{Pym}^{+}$in the HCN loss channel failed because of (i) high metastable decay background, which exceeds by far the achieved IRPD yield and/or (ii) the high energy required for dissociation $\left(\sim 200-300 \mathrm{~kJ} \mathrm{~mol}^{-1}\right) .^{51,57-59,68}$

Cluster formation of $\mathrm{Pym}^{+}$with $\mathrm{N}_{2}$ occurs mainly through two different ligand binding motifs, namely $\pi$-bonding to the aromatic ring and linear $\mathrm{CH} \cdots \mathrm{N}_{2}$ ionic H-bonding (Fig. 2). The latter class leads to three different planar isomers $\left(C_{\mathrm{s}}\right.$ or $\left.C_{2 \mathrm{v}}\right)$ because of the three nonequivalent $\mathrm{CH}$ groups. The highest $D_{0}$ value of the $\mathrm{Pym}^{+}-\mathrm{N}_{2}(\pi)$ dimer $\left(D_{0}=868 \mathrm{~cm}^{-1}, C_{\mathrm{s}}\right)$ results mostly from the strong charge-quadrupole and charge-induced dipole interaction between $\mathrm{Pym}^{+}$and $\mathrm{N}_{2}$, along with minor dispersion forces involving the highly polarizable aromatic $\pi$ electrons. The $\pi$-attachment negligibly affects the ring structure, and thus the $\nu_{\mathrm{CH}}$ frequencies probed in this work remain nearly unchanged from those of bare $\operatorname{Pym}^{+}\left(\Delta \nu_{\mathrm{CH}} \leq 2 \mathrm{~cm}^{-1}\right.$, Table 1 and Fig. 3). The slight frequency increase arises from the small noncooperative effect induced by $\pi$-bonded $\mathrm{N}_{2}$ and agrees with the minor computed reduction in the $\mathrm{C}-\mathrm{H}$ bond lengths $\left(\Delta r_{\mathrm{CH}} \leq 0.2 \mathrm{~mA}\right)$. Among the three nonequivalent $\mathrm{H}$-bonded isomers, the $\mathrm{CH} \cdots \mathrm{N}_{2} \mathrm{H}$-bond is the strongest in the $\mathrm{Pym}^{+}-\mathrm{N}_{2}(\mathrm{C} 4)$ dimer $\left(D_{0}=784 \mathrm{~cm}^{-1}\right)$, which is rationalized by the highest acidity of the corresponding $\mathrm{CH}$ group, as is evidenced from its longest $\mathrm{C}-\mathrm{H}$ bond and highest atomic charge $(0.275 e)$ in bare $\mathrm{Pym}^{+}$(Fig. 2 and Fig. S4, ESI $\dagger$ ). This relatively strong $\mathrm{CH} \cdots \mathrm{N}_{2} \mathrm{H}$-bond lowers the bound $\nu_{\mathrm{C} 4 \mathrm{H}}^{\mathrm{b}}$ stretch frequency of the $\mathrm{C} 4 \mathrm{H}$ donor (by $23 \mathrm{~cm}^{-1}$ ) and enhances its IR intensity by a factor 7 to $200 \mathrm{~km} \mathrm{~mol}^{-1}$ (Fig. 3), while the properties of the three remaining free $\mathrm{CH}$ groups remain nearly unaffected $\left(\Delta \nu_{\mathrm{CH}}^{\mathrm{f}} \leq 1 \mathrm{~cm}^{-1}\right)$. Similar results are also predicted 
Table 2 Positions, widths (fwhm in parentheses), and suggested vibrational and isomer assignments of the transitions observed in the IRPD spectra of $\mathrm{C}_{3} \mathrm{H}_{3} \mathrm{~N}^{+}$and $\mathrm{C}_{3} \mathrm{H}_{3} \mathrm{~N}^{+}-\mathrm{L}\left(\mathrm{L}=\mathrm{Ar} / \mathrm{N}_{2}\right)$ compared to frequencies calculated the B3LYP-D3/aug-cc-pVTZ level (Fig. 4-6). All values are given in $\mathrm{cm}^{-1}$

\begin{tabular}{|c|c|c|c|c|}
\hline & Exp. $\left(\mathrm{cm}^{-1}\right)$ & Calc. $^{a}\left(\mathrm{~cm}^{-1}\right)$ & Vibration & Isomer \\
\hline $\mathrm{C}_{3} \mathrm{H}_{3} \mathrm{~N}^{+}$ & D 3160 (200) & $\begin{array}{l}3229\left(334, a^{\prime}\right) \\
3155\left(46, a^{\prime}\right) \\
3040\left(39, a^{\prime}\right) \\
3231\left(333, a^{\prime}\right) \\
3149\left(62, a^{\prime}\right) \\
3000\left(30, a^{\prime}\right)\end{array}$ & $\begin{array}{c}\nu_{\mathrm{CH}}^{\mathrm{f}} \\
\nu_{\mathrm{CH}}^{\mathrm{f}} \\
\nu_{\mathrm{CH}}^{\mathrm{f}} \\
\nu_{\mathrm{CH}}^{\mathrm{f}} \\
\nu_{\mathrm{CH}}^{\mathrm{f}} \\
\nu_{\mathrm{CH}}^{\mathrm{f}}\end{array}$ & $\begin{array}{l}5 \\
5 \\
5 \\
4 \\
4 \\
4\end{array}$ \\
\hline $\mathrm{C}_{3} \mathrm{H}_{3} \mathrm{~N}^{+}-\mathrm{Ar}$ & $\begin{array}{l}\text { D1 } 3232(16) \\
\text { D2 } 3170(26)\end{array}$ & $\begin{array}{l}3362\left(2370, a_{1}\right) \\
3347\left(2119, a^{\prime}\right) \\
3347\left(2131, a^{\prime}\right) \\
3235\left(313, a^{\prime}\right) \\
3151\left(785, a^{\prime}\right) \\
3148\left(768, a^{\prime}\right) \\
3150\left(53, a^{\prime}\right) \\
3156\left(47, a^{\prime}\right) \\
3157\left(43, a^{\prime}\right)\end{array}$ & $\begin{array}{l}\nu_{\mathrm{NH}}^{\mathrm{b}} \\
\nu_{\mathrm{NH}}^{\mathrm{b}} \\
\nu_{\mathrm{NH}}^{\mathrm{b}} \\
\nu_{\mathrm{CH}}^{\mathrm{f}} \\
\nu_{\mathrm{CH}}^{\mathrm{b}} \\
\nu_{\mathrm{CH}}^{\mathrm{b}} \\
\nu_{\mathrm{CH}}^{\mathrm{f}} \\
\nu_{\mathrm{CH}}^{\mathrm{f}} \\
\nu_{\mathrm{CH}}^{\mathrm{f}}\end{array}$ & $\begin{array}{l}\text { 1-Ar } \\
\text { 3-Ar } \\
2-\mathrm{Ar} \\
5-\operatorname{Ar}(\pi) \\
4-\mathrm{Ar} \\
5-\operatorname{Ar}(\mathrm{H}) \\
\text { 4-Ar } \\
5-\mathrm{Ar}(\mathrm{H}) \\
5-\operatorname{Ar}(\pi)\end{array}$ \\
\hline $\mathrm{C}_{3} \mathrm{H}_{3} \mathrm{~N}^{+}-\mathrm{N}_{2}$ & $\begin{array}{l}\text { D3 } 3170(40) \\
\text { E } 3118(60)\end{array}$ & $\begin{array}{l}3150\left(61, a^{\prime}\right) \\
3156\left(43, a^{\prime}\right) \\
3144\left(3357, a_{1}\right) \\
3133\left(652, a^{\prime}\right) \\
3131\left(2348, a^{\prime}\right) \\
3132\left(2415, a^{\prime}\right) \\
3128\left(626, a^{\prime}\right) \\
3055\left(1076, a^{\prime}\right) \\
3053\left(959, a^{\prime}\right)\end{array}$ & $\begin{array}{l}\nu_{\mathrm{CH}}^{\mathrm{f}} \\
\nu_{\mathrm{CH}}^{\mathrm{f}} \\
\nu_{\mathrm{NH}}^{\mathrm{b}} \\
\nu_{\mathrm{NH}}^{\mathrm{b}} / \nu_{\mathrm{CH}}^{\mathrm{f}}(\mathrm{s}) \\
\nu_{\mathrm{NH}}^{\mathrm{b}} / \nu_{\mathrm{CH}}^{\mathrm{f}}(\mathrm{a}) \\
\nu_{\mathrm{NH}}^{\mathrm{b}} \\
\nu_{\mathrm{CH}}^{\mathrm{f}} \\
\nu_{\mathrm{CH}}^{\mathrm{b}} \\
\nu_{\mathrm{CH}}^{\mathrm{b}}\end{array}$ & $\begin{array}{l}4-\mathrm{N}_{2} \\
5-\mathrm{N}_{2} \\
1-\mathrm{N}_{2} \\
3-\mathrm{N}_{2} \\
3-\mathrm{N}_{2} \\
2-\mathrm{N}_{2} \\
2-\mathrm{N}_{2} \\
4-\mathrm{N}_{2} \\
5-\mathrm{N}_{2}\end{array}$ \\
\hline $\mathrm{C}_{3} \mathrm{H}_{3} \mathrm{~N}^{+}-\left(\mathrm{N}_{2}\right)_{2}$ & $\begin{array}{l}\text { D3 } 3171(13) \\
\text { E } 3132(30)\end{array}$ & & $\begin{array}{l}\nu_{\mathrm{CH}}^{\mathrm{f}} \\
\nu_{\mathrm{CH}}^{\mathrm{f}} \\
\nu_{\mathrm{NH}}^{\mathrm{b}} \\
\nu_{\mathrm{NH}}^{\mathrm{b}} / \nu_{\mathrm{CH}}^{\mathrm{f}}(\mathrm{s}) \\
\nu_{\mathrm{NH}}^{\mathrm{b}} / \nu_{\mathrm{CH}}^{\mathrm{f}}(\mathrm{a}) \\
\nu_{\mathrm{NH}}^{\mathrm{b}} \\
\nu_{\mathrm{CH}}^{\mathrm{f}} \\
\nu_{\mathrm{CH}}^{\mathrm{b}} \\
\nu_{\mathrm{CH}}^{\mathrm{b}}\end{array}$ & $\begin{array}{l}4-\left(N_{2}\right)_{2} \\
5-\left(N_{2}\right)_{2} \\
1-\left(N_{2}\right)_{2} \\
3-\left(N_{2}\right)_{2} \\
3-\left(N_{2}\right)_{2} \\
2-\left(N_{2}\right)_{2} \\
2-\left(N_{2}\right)_{2} \\
4-\left(N_{2}\right)_{2} \\
5-\left(N_{2}\right)_{2}\end{array}$ \\
\hline $\mathrm{C}_{3} \mathrm{H}_{3} \mathrm{~N}^{+}-\left(\mathrm{N}_{2}\right)_{3}$ & $\begin{array}{l}\text { D3 } 3172(14) \\
\text { E } 3141(16)\end{array}$ & & $\begin{array}{l}\nu_{\mathrm{CH}}^{\mathrm{f}} \\
\nu_{\mathrm{CH}}^{\mathrm{f}} \\
\nu_{\mathrm{NH}}^{\mathrm{b}} \\
\nu_{\mathrm{NH}}^{\mathrm{b}} / \nu_{\mathrm{CH}}^{\mathrm{f}}(\mathrm{s}) \\
\nu_{\mathrm{NH}}^{\mathrm{b}} / \nu_{\mathrm{CH}}^{\mathrm{f}}(\mathrm{a}) \\
\nu_{\mathrm{NH}}^{\mathrm{b}} \\
\nu_{\mathrm{CH}}^{\mathrm{f}} \\
\nu_{\mathrm{CH}}^{\mathrm{b}} \\
\nu_{\mathrm{CH}}^{\mathrm{b}}\end{array}$ & $\begin{array}{l}4-\left(N_{2}\right)_{3} \\
5-\left(N_{2}\right)_{3} \\
1-\left(N_{2}\right)_{3} \\
3-\left(N_{2}\right)_{3} \\
3-\left(N_{2}\right)_{3} \\
2-\left(N_{2}\right)_{3} \\
2-\left(N_{2}\right)_{3} \\
4-\left(N_{2}\right)_{3} \\
5-\left(N_{2}\right)_{3}\end{array}$ \\
\hline
\end{tabular}

${ }^{a}$ Vibrational symmetry species and IR intensities (in $\mathrm{km} \mathrm{mol}^{-1}$ ) are listed in parentheses.

for the other two less stable H-bonded isomers, $\mathrm{Pym}^{+}-\mathrm{N}_{2}(\mathrm{C} 2)$ and Pym $^{+}-\mathrm{N}_{2}$ (C5), with $D_{0}=775$ and $690 \mathrm{~cm}^{-1}$ (Fig. 2 and 3). For each of the two isomers, the frequency of the intense $\nu_{\mathrm{CH}}^{\mathrm{b}}$ mode is calculated near $3100 \mathrm{~cm}^{-1}\left(\nu_{\mathrm{C} 2 \mathrm{H} / \mathrm{C} 5 \mathrm{H}}^{\mathrm{b}}=3100 / 3097 \mathrm{~cm}^{-1}\right.$, $-\Delta \nu_{\mathrm{C} 2 \mathrm{H} / \mathrm{C} 5 \mathrm{H}}^{\mathrm{b}}=17 / 6 \mathrm{~cm}^{-1}$ ) because of its higher intrinsic frequency, resulting from its inherently weaker acidic nature $\left(\nu_{\mathrm{C} 2 \mathrm{H} / \mathrm{C} 5 \mathrm{H}}=3117 / 3103 \mathrm{~cm}^{-1}\right.$ for $\left.\mathrm{Pym}^{+}\right)$.

The experimental $\mathrm{Pym}^{+}-\mathrm{N}_{2}$ spectrum in Fig. 3 features a clear doublet A1 and A2 at 3125 and $3111 \mathrm{~cm}^{-1}$, along with an intense
Table 3 Positions, widths (fwhm in parentheses), and suggested vibrational and isomer assignments of the transitions observed in the IRPD spectra of $\mathrm{C}_{2} \mathrm{H}_{2}{ }^{+}-\mathrm{L}\left(\mathrm{L}=\mathrm{Ar} / \mathrm{N}_{2}\right)$ compared to frequencies calculated the B3LYP-D3/aug-cc-pVTZ level (Fig. 7). All values are given in $\mathrm{cm}^{-1}$. For comparison, spectral data of $\mathrm{HCCH}^{+}$are provided

\begin{tabular}{lllll}
\hline & Exp. $\left(\mathrm{cm}^{-1}\right)$ & Calc. $^{a}\left(\mathrm{~cm}^{-1}\right)$ & Vibration & Isomer \\
\hline $\mathrm{C}_{2} \mathrm{H}_{2}{ }^{+}$ & $\sim 3234^{b}$ & $3225\left(0, \sigma_{\mathrm{g}}\right)$ & $\nu_{1}$ & $\mathrm{HCCH}^{+}$ \\
& $3136^{b}$ & $3123\left(443, \sigma_{\mathrm{u}}\right)$ & $\nu_{3}$ & $\mathrm{HCCH}^{+}$ \\
$\mathrm{C}_{2} \mathrm{H}_{2}{ }^{+}-\mathrm{Ar}$ & $\mathrm{F} 13234(15)^{b}$ & $3258\left(2, \mathrm{a}^{\prime}\right)$ & $\nu_{1}$ & $\mathrm{HCCH}^{+}-\mathrm{Ar}(\pi)$ \\
& $\mathrm{F} 23153(77)$ & $3160\left(373, \mathrm{a}^{\prime}\right)$ & $\nu_{3}$ & $\mathrm{HCCH}^{+}-\mathrm{Ar}(\pi)$ \\
$\mathrm{C}_{2} \mathrm{H}_{2}{ }^{+}-\mathrm{N}_{2}$ & $\mathrm{~F} 23165(30)$ & $3166\left(358, \mathrm{a}^{\prime}\right)$ & $\nu_{3}$ & $\mathrm{HCCH}^{+}-\mathrm{N}_{2}(\pi)$ \\
& F3 3035 (68) & $2962(1063, \sigma)$ & $\nu_{\mathrm{CH}}^{\mathrm{b}}$ & $\mathrm{HCCH}^{+}-\mathrm{N}_{2}(\mathrm{H})$ \\
${ }^{a}$ Vibrational symmetry species and IR intensities (in $\left.\mathrm{km} \mathrm{mol}^{-1}\right)$ are \\
listed in parentheses. ${ }^{b}$ Ref. 80 and 98.
\end{tabular}

band $\mathrm{B}$ at $3046 \mathrm{~cm}^{-1}$ and a weak transition $\mathrm{C}$ at $3001 \mathrm{~cm}^{-1}$. The relative intensities and positions of the first three bands show good correspondence with the spectrum computed for the most stable $\operatorname{Pym}^{+}-\mathrm{N}_{2}(\pi)$ isomer $\left(3119,3103,3032 \mathrm{~cm}^{-1}\right)$, with deviations of less than $15 \mathrm{~cm}^{-1}$ (which is of the order of the widths of the bands). The relative intensities of the bands $\mathrm{A} 1, \mathrm{~A} 2$, and $\mathrm{B}$ bands quantitatively match the predicted pattern, indicating a dominant contribution of the most stable $\pi$-bonded isomer. Similar agreement is not observed for the two H-bound $\mathrm{Pym}^{+}-\mathrm{N}_{2}(\mathrm{C} 5)$ and $\mathrm{Pym}^{+}-\mathrm{N}_{2}(\mathrm{C} 2)$ local minima. Particularly, their predicted intense $\nu_{\mathrm{C} 2 \mathrm{H} / \mathrm{C} 5 \mathrm{H}}^{\mathrm{b}}$ modes near $3100 \mathrm{~cm}^{-1}$ are not consistent with the intensity observed for band A2, suggesting no (or at most very low) population of these two isomers. This is further corroborated by their smaller binding energies $\left(D_{0}=775\right.$ and $\left.690 \mathrm{~cm}^{-1}\right)$. Therefore, we will not consider these two structures for further cluster growth. The remaining small band $\mathrm{C}$ at $3001 \mathrm{~cm}^{-1}$ agrees well with the $\nu_{\mathrm{C} 4 \mathrm{H}}^{\mathrm{b}}$ mode of $\mathrm{Pym}^{+}-$ $\mathrm{N}_{2}(\mathrm{C} 4)$ calculated at $3008 \mathrm{~cm}^{-1}$, the unique spectroscopic signature of this most stable $\mathrm{H}$-bonded isomer. Its other predicted modes overlap with the $\mathrm{CH}$ stretch bands $\mathrm{A} 1, \mathrm{~A} 2$, and $\mathrm{B}$ predominantly assigned to the $\pi$-bonded global minimum. The substantial discrepancy between the experimental and calculated intensity ratios of the $\mathrm{CH}$ stretch bands demonstrates the significantly smaller population of $\mathrm{Pym}^{+}-\mathrm{N}_{2}(\mathrm{C} 4)$ compared to $\mathrm{Pym}^{+}-\mathrm{N}_{2}(\pi)$, which is in line with their thermochemical data $\left(D_{0}=784 v s .868 \mathrm{~cm}^{-1}\right)$. Taking the relative intensity of bands $C$ and $B(1: 6)$ along with the computed IR oscillator strengths $(4: 1)$ yields a crude estimate for the abundance ratio of $1: 24$ (or $4 \%$ ) for the $\mathrm{C} 4$ and $\pi$ isomers.

Attachment of a second $\mathrm{N}_{2}$ ligand to $\operatorname{Pym}^{+}-\mathrm{N}_{2}(\pi)$ on the opposite side of the aromatic ring leads to the most stable Pym $^{+}-\left(\mathrm{N}_{2}\right)_{2}(\pi / \pi)$ trimer $\left(C_{2 \mathrm{v}}\right)$ with $D_{0}=1724 \mathrm{~cm}^{-1}$ (Fig. 2). The two $\mathrm{N}_{2}$ ligands are equivalent and their bonding is only slightly weaker than in the dimer, because effective shielding of the aromatic ring causes only small nonadditive noncooperative effects. Similar to the $n=1$ case, the second $\pi$-addition has a negligible influence on the $\mathrm{C}-\mathrm{H}$ bond properties of $\mathrm{Pym}^{+}$. The $\nu_{\mathrm{CH}}$ modes and their IR intensity remain almost unchanged $\left(\Delta \nu_{\mathrm{CH}} \leq 3 \mathrm{~cm}^{-1}\right)$. We consider in Fig. 2 two further isomers resulting from attachment of the second $\mathrm{N}_{2}$ ligand to the much less abundant $\mathrm{Pym}^{+}-\mathrm{N}_{2}(\mathrm{C} 4)$ dimer, namely $\mathrm{Pym}^{+}-\left(\mathrm{N}_{2}\right)_{2}(\mathrm{C} 4 / \pi)$ and Pym $^{+}-\left(\mathrm{N}_{2}\right)_{2}(\mathrm{C} 4 / \mathrm{C} 6)$. The $\pi$-bonded $\mathrm{N}_{2}$ in the first isomer 

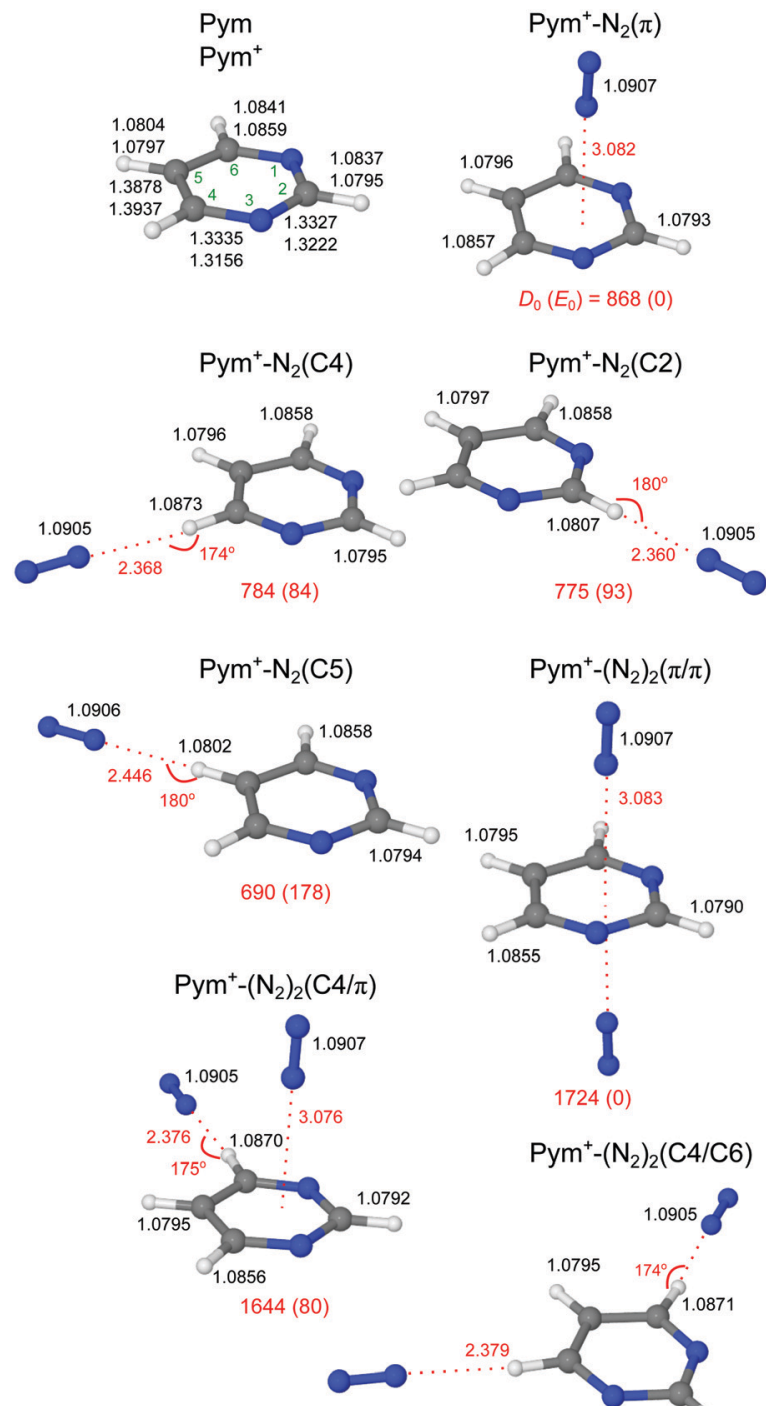

....

(177)

Fig. 2 Optimized structures of Pym, $\mathrm{Pym}^{+}$, and most stable isomers of Pym $^{+}-\left(\mathrm{N}_{2}\right)_{1-2}$ calculated at the B3LYP-D3/aug-cc-pVTZ level. Binding energies $\left(D_{0}\right)$ and bond lengths are given in $\mathrm{cm}^{-1}$ and $\AA$, respectively. Numbers in parentheses correspond to relative energies in $\mathrm{cm}^{-1}\left(E_{0}\right)$. For Pym, the atomic numbering according to IUPAC is given as well.

does not perturb the $\mathrm{Pym}^{+}-\mathrm{N}_{2}(\mathrm{C} 4)$ dimer $\left(\Delta \nu_{\mathrm{CH}} \leq 3 \mathrm{~cm}^{-1}\right)$. On the other hand, in $\operatorname{Pym}^{+}-\left(\mathrm{N}_{2}\right)_{2}(\mathrm{C} 4 / \mathrm{C} 6)$ the $\mathrm{C} 6-\mathrm{H}$ bond slightly elongates upon H-bonding $\left(\Delta r_{\mathrm{CH}}=1.3 \mathrm{~m} \AA\right)$. The corresponding symmetric and antisymmetric $\nu_{\mathrm{C} 4 \mathrm{H} / \mathrm{C} 6 \mathrm{H}}^{\mathrm{b}}$ modes are calculated at 3011 and $3010 \mathrm{~cm}^{-1}$, respectively, with the latter being more intense $\left(I_{\mathrm{CH}}=79\right.$ vs. $\left.301 \mathrm{~km} \mathrm{~mol}^{-1}\right)$. This trimer with two $\mathrm{CH} \cdots \mathrm{N}_{2}$ H-bonds is slightly less stable than $\mathrm{Pym}^{+}-\left(\mathrm{N}_{2}\right)_{2}(\mathrm{C} 4 / \pi)$ by $\Delta D_{0}=98 \mathrm{~cm}^{-1}$, resulting from the higher $\pi$-affinity of the $\mathrm{N}_{2}$ ligand (as compared to H-bonding).

The appearance of the $n=2$ spectrum is very similar to the dimer spectrum with respect to both frequency and relative intensity of the four bands A-C, with frequency shifts of less than $3 \mathrm{~cm}^{-1}$ upon attachment of the second $\mathrm{N}_{2}$ ligand (Fig. 3). However, the doublet structure now appears as two clearly

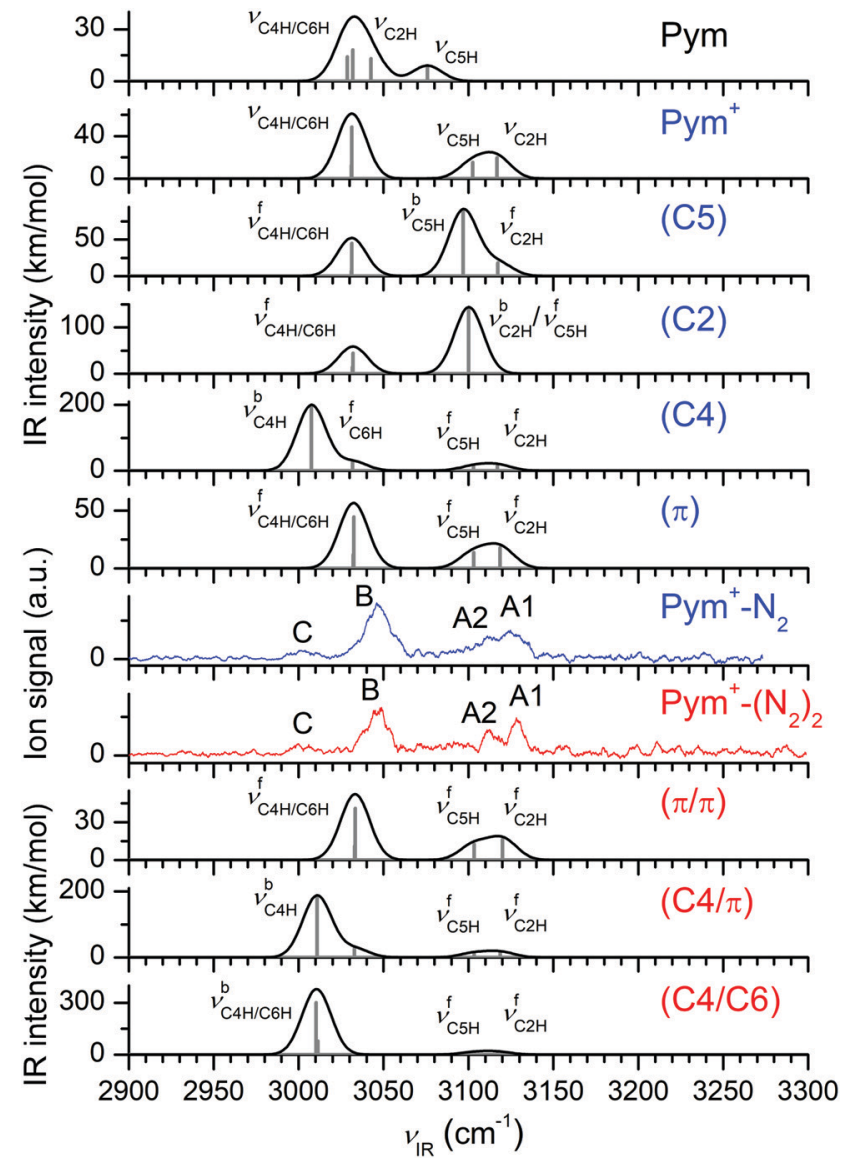

Fig. 3 Comparison of experimental IRPD spectra of Pym ${ }^{+}-\left(\mathrm{N}_{2}\right)_{1-2}$ with linear IR absorption spectra of Pym, Pym ${ }^{+}$, and most stable Pym ${ }^{+}-\left(\mathrm{N}_{2}\right)_{1-2}$ isomers calculated at the B3LYP-D3/aug-cc-pVTZ level (Fig. 2 and Table 1).

separated peaks at 3128 (A1) and $3112(\mathrm{~A} 2) \mathrm{cm}^{-1}$, due to colder clusters and smaller rotational constants leading to narrower transitions for the larger cluster. The intense band $\mathrm{B}$ at $3048 \mathrm{~cm}^{-1}$ and the weak transition $\mathrm{C}$ at $3003 \mathrm{~cm}^{-1}$ remain almost unshifted. Similar to the dimer case, the predicted $\nu_{\mathrm{CH}}$ modes of the $\mathrm{Pym}^{+}-\left(\mathrm{N}_{2}\right)_{2}(\pi / \pi)$ trimer at 3120,3103 , and $3033 \mathrm{~cm}^{-1}$ nicely agree with the three dominant bands A1, $\mathrm{A} 2$, and $\mathrm{B}$, respectively. The calculation satisfactorily reproduces the slight experimental blue shifts of $1-3 \mathrm{~cm}^{-1}$ (Table 1), which originate from the noncooperativity induced by the $\pi$-bound $N_{2}$ ligand. Thus, the most stable $\operatorname{Pym}^{+}-\left(\mathrm{N}_{2}\right)_{2}(\pi / \pi)$ isomer dominates the experimental spectrum. In analogy to the dimer spectrum, band $\mathrm{C}\left(3003 \mathrm{~cm}^{-1}\right)$ in the trimer spectrum is explained by the $\nu_{\mathrm{CH}}^{\mathrm{b}} \operatorname{mode}(\mathrm{s})$ of both the $(\mathrm{C} 4 / \pi)$ and $(\mathrm{C} 4 / \mathrm{C} 6)$ isomers. From the relative intensities of bands $\mathrm{B}$ and $\mathrm{C}$, the contribution of these two local minima is estimated to be below $5 \%$ of the abundance of the most stable calculated Pym $^{+}-\left(\mathrm{N}_{2}\right)_{2}(\pi / \pi)$ global minimum. From the $\pi$-bonded isomers of $\operatorname{Pym}^{+}-\left(\mathrm{N}_{2}\right)_{n}$, we can reliably and accurately estimate the four $\mathrm{CH}$ stretch frequencies of bare $\mathrm{Pym}^{+}$as $3124 \pm 2\left(\nu_{\mathrm{C} 2 \mathrm{H}}\right)$, $3112 \pm 2\left(\nu_{\mathrm{C} 5 \mathrm{H}}\right), 3045 \pm 2\left(\nu_{\mathrm{C} 4 \mathrm{H} / \mathrm{H}}(\mathrm{s})\right)$, and $3045 \pm 2 \mathrm{~cm}^{-1}\left(\nu_{\mathrm{C} 4 \mathrm{H} / 6 \mathrm{H}}(\mathrm{a})\right)$ by taking into account the predicted small complexation shifts. 
The IRPD signal of Pym ${ }^{+}-\left(\mathrm{N}_{2}\right)_{2}$ is observed exclusively in the $\mathrm{Pym}^{+}$fragment channel. This result is consistent with the total binding energy of $D_{0}=1724 \mathrm{~cm}^{-1}$, which is much smaller than the energy of a single photon absorbed in the $\mathrm{CH}$ stretch range $\left(\nu_{\mathrm{IR}}>3000 \mathrm{~cm}^{-1}\right)$.

\section{$4.2 \mathrm{C}_{3} \mathrm{H}_{3} \mathrm{~N}^{+}$monomer $(m / z=53)$}

In our EI source, $\mathrm{Pym}^{+}$mainly disintegrates into the $\mathrm{C}_{3} \mathrm{H}_{3} \mathrm{~N}^{+}$ fragment $(\mathrm{m} / \mathrm{z} 53)$, which further dissociates into the smaller $\mathrm{C}_{2} \mathrm{H}_{2}{ }^{+}$fragment $(\mathrm{m} / \mathrm{z} 26)$. This is demonstrated by the mass spectrum of the EI source, as well as CID spectra of the massselected $\mathrm{Pym}^{+}$and $\mathrm{C}_{3} \mathrm{H}_{3} \mathrm{~N}^{+}$radical cations, both of which show exclusive loss of HCN (Fig. S1 and S2, ESI $\dagger$ ). Mass spectrometric studies on isotopically-labelled Pym indicate that H4C4N3 is the by far dominant neutral fragment. ${ }^{60}$ We consider all conceivable isomers and IR spectra of the $\mathrm{C}_{3} \mathrm{H}_{3} \mathrm{~N}^{+}$ion in Fig. 4 and Fig. S5 (1-13) (ESI $\dagger$ ), which were suggested as the most probable isomers by previous computational and thermochemical studies. ${ }^{58,61,62,64,67,68,94}$ These show a considerable structural variety and spread in energy. For example, a systematic global optimization search yielded 17 isomers within $200 \mathrm{~kJ} \mathrm{~mol}^{-1}$. $^{67}$ Consistent with the previous reports, ${ }^{58,61,62,64,67,94}$ the $\mathrm{H}_{2} \mathrm{CCCNH}^{+}$isomer $\left(1, \mathrm{H}_{2} \mathrm{C}=\mathrm{C}=\mathrm{C}=\mathrm{N}^{+} \mathrm{H}, C_{2 \mathrm{v}},{ }^{2} \mathrm{~B}_{2}\right)$ with a linear CCCN backbone is calculated to be by far the most stable $\mathrm{C}_{3} \mathrm{H}_{3} \mathrm{~N}^{+}$structure, with an energy gap of $\sim 50 \mathrm{~kJ} \mathrm{~mol}^{-1}$ to the other isomers. This ion features a free $\mathrm{NH}$ group and its

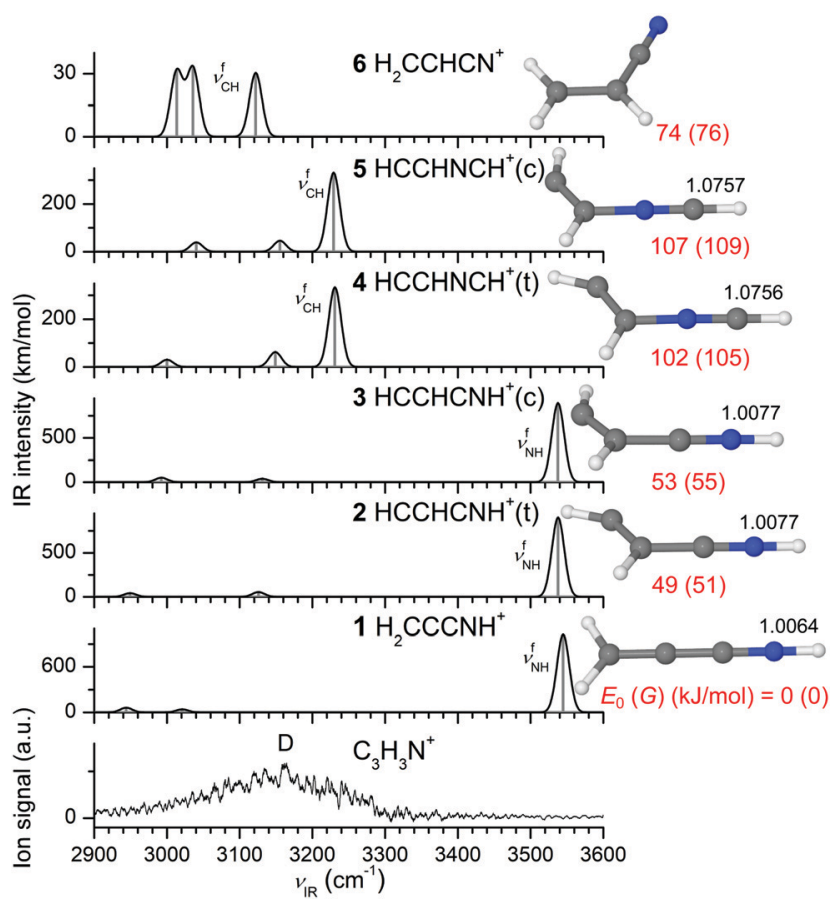

Fig. 4 Comparison of experimental IRPD spectrum of $\mathrm{C}_{3} \mathrm{H}_{3} \mathrm{~N}^{+}$recorded in the $\mathrm{HCN}$ loss channel with linear IR absorption spectra of various $\mathrm{C}_{3} \mathrm{H}_{3} \mathrm{~N}^{+}$isomers along with the corresponding optimized structures calculated at the B3LYP-D3/aug-cc-pVTZ level. The relative energies $\left(E_{0}\right)$, free energies $(G)$ in parentheses and bond lengths are given in $\mathrm{kJ} \mathrm{mol}^{-1}$ and $\AA$, respectively. A comparison with spectra computed for other $\mathrm{C}_{3} \mathrm{H}_{3} \mathrm{~N}^{+}$isomers is available in Fig. S5 (ESI†). characteristic $\nu_{\mathrm{NH}}^{\mathrm{f}}$ mode calculated at $3545 \mathrm{~cm}^{-1}$ dominates its IR spectrum in the $\mathrm{CH}$ and $\mathrm{NH}$ stretch ranges $\left(I_{\mathrm{NH}}=\right.$ $1022 \mathrm{~km} \mathrm{~mol}^{-1}$ ). The next stable $\mathrm{C}_{3} \mathrm{H}_{3} \mathrm{~N}^{+}$monomers are the cis/trans isomers of $\mathrm{HCCHCNH}^{+}\left(3 / 2, \mathrm{HC}=\mathrm{C}(\mathrm{H})-\mathrm{C}^{+}=\mathrm{NH}\right.$, $\left.C_{\mathrm{s}},{ }^{2} \mathrm{~A}^{\prime}\right)$ at $E_{0}=53 / 49 \mathrm{~kJ} \mathrm{~mol}^{-1}$, which also have a CCCN backbone and a terminal $\mathrm{NH}$ group with similar $\mathrm{NH}$ stretch properties $\left(\nu_{\mathrm{NH}}^{\mathrm{f}}=3538 \mathrm{~cm}^{-1}\right)$. Further isomers with a CCCN backbone and terminal $\mathrm{NH}$ group are rather unstable (11/12, cis-/trans-HCCCHNH ${ }^{+}, \mathrm{H}-\mathrm{C} \equiv \mathrm{C}-\mathrm{C}^{+}(\mathrm{H})=\mathrm{NH}, E_{0}>130 \mathrm{~kJ} \mathrm{~mol}^{-1}$, $C_{\mathrm{s}},{ }^{2} \mathrm{~A}^{\prime}$, Fig. S5, ESI $\dagger$ ), and were not considered in all previous systematic calculations, ${ }^{58,61,62,67,94}$ with one exception. ${ }^{64}$ Acrylonitrile $\left(6, \mathrm{H}_{2} \mathrm{CCHCN}^{+}, \quad \mathrm{H}_{2} \mathrm{C}=\mathrm{C}^{+}(\mathrm{H})-\mathrm{C} \equiv \mathrm{N}, \quad C_{\mathrm{s}}, \quad{ }^{2} \mathrm{~A}^{\prime \prime}, \quad E_{0}=\right.$ $74 \mathrm{~kJ} \mathrm{~mol}^{-1}$ ), the initially proposed candidate of the elusive $\mathrm{C}_{3} \mathrm{H}_{3} \mathrm{~N}^{+}$structure, ${ }^{56}$ also exhibits a bent CCCN backbone but lacks a NH group. Its characteristic $\mathrm{CH}$ stretch bands appear as three weak transitions between 3000 and $3140 \mathrm{~cm}^{-1}\left(I_{\mathrm{CH}} \sim\right.$ $30 \mathrm{~km} \mathrm{~mol}^{-1}$ ). Two further high-energy nonplanar structures with a cyclic CCC ring and a $\mathrm{NH}$ group are also computed, namely $\mathrm{HCCHCNH}^{+}(r)\left(9, C_{1},{ }^{2} \mathrm{~A}\right)$ and $\mathrm{HCCCHNH}^{+}(\mathrm{b})\left(13, C_{\mathrm{s}},{ }^{2} \mathrm{~A}^{\prime}\right)$ at 83 and $299 \mathrm{~kJ} \mathrm{~mol}^{-1}$. The IR spectrum of a cyclic CCC structure with a $\mathrm{NH}_{2}$ group $\left(\mathbf{1 0}, \mathrm{CCHCHNH}_{2}{ }^{+}, C_{\mathrm{s}},{ }^{2} \mathrm{~A}^{\prime}\right)$ at $103 \mathrm{~kJ} \mathrm{~mol}^{-1}$ is characterized by two NH stretch modes at 3335 and $3395 \mathrm{~cm}^{-1}$, respectively. Two isomers with a (nearly) linear CCNC backbone, $\mathrm{H}_{2} \mathrm{CNCCH}^{+}\left(7, \mathrm{H}_{2} \mathrm{C}=\mathrm{N}^{+}-\mathrm{C} \equiv \mathrm{CH}, C_{2 \mathrm{v}},{ }^{2} \mathrm{~B}_{2}\right)$ and $\mathrm{H}_{2} \mathrm{CCNCH}^{+}$ (8, $\left.\mathrm{H}_{2} \mathrm{C}=\mathrm{C}^{+}-\mathrm{N}=\mathrm{CH}, C_{\mathrm{s}},{ }^{2} \mathrm{~A}^{\prime}\right)$, are calculated at relatively low energy $\left(E_{0}=61\right.$ and $\left.67 \mathrm{~kJ} \mathrm{~mol}^{-1}\right)$. Each of them exhibits a characteristic intense $\nu_{\mathrm{CH}}^{\mathrm{f}}$ mode at $3246\left(I_{\mathrm{CH}}=187 \mathrm{~km} \mathrm{~mol}^{-1}\right)$ and $3138 \mathrm{~cm}^{-1}\left(I_{\mathrm{CH}}=269 \mathrm{~km} \mathrm{~mol}^{-1}\right)$, respectively. We further calculate the cis and trans forms of the kinetically favored $\mathrm{HCCHNCH}^{+}$isomer (5 and $4, \mathrm{HC}=\mathrm{C}(\mathrm{H})-\mathrm{N}=\mathrm{C}^{+} \mathrm{H}, E_{0}=107$ and $\left.102 \mathrm{~kJ} \mathrm{~mol}^{-1}, C_{\mathrm{s}},{ }^{2} \mathrm{~A}^{\prime \prime}\right) .{ }^{58,60,67,68}$ Unlike all other isomers, which demand a significant activation barrier for their formation, 4 and 5 exhibit a suitable CCNC backbone that facilitates fragmentation of the $\mathrm{Pym}^{+}$ring via simple neutral HCN elimination. ${ }^{58,60,67,68}$ Their intense $\nu_{\mathrm{CH}}^{\mathrm{f}}$ modes are predicted around $3230 \mathrm{~cm}^{-1}$ $\left(I_{\mathrm{CH}} \sim 330 \mathrm{~km} \mathrm{~mol}^{-1}\right)$.

The IRPD spectrum of bare $\mathrm{C}_{3} \mathrm{H}_{3} \mathrm{~N}^{+}$recorded in the $\mathrm{C}_{2} \mathrm{H}_{2}{ }^{+}$ fragment ion channel ( $\mathrm{HCN}$ loss, Fig. 4) is dominated by a broad transition (D) ranging from 2950 to $3290 \mathrm{~cm}^{-1}$ and peaking near $3160 \mathrm{~cm}^{-1}$ (FWHM $\sim 200 \mathrm{~cm}^{-1}$ ). The signal to noise ratio is limited because of the large background arising from metastable decay of hot ions, which keep high internal energy after $\mathrm{Pym}^{+} \rightarrow \mathrm{C}_{3} \mathrm{H}_{3} \mathrm{~N}^{+}$fragmentation due to insufficient cooling in the supersonic expansion after HCN elimination. The broad and unstructured spectrum results from the substantial internal energy of the bare $\mathrm{C}_{3} \mathrm{H}_{3} \mathrm{~N}^{+}$ion, which becomes much narrower upon tagging with an inert $\mathrm{Ar} / \mathrm{N}_{2}$ ligand (Fig. 1) leading to the observation of much colder ions. The unfocussed IR laser beam allows only for single-photon absorption processes, so that only ions with energy around $3000 \mathrm{~cm}^{-1}$ below the dissociation threshold can be detected upon IRPD. Because HCN loss requires typically much higher energies for all $\mathrm{C}_{3} \mathrm{H}_{3} \mathrm{~N}^{+}$ions considered, ${ }^{58,61,62,67,94}$ only ions with very high internal energy are probed in the recorded IRPD spectrum, leading to the observation of hot bands and sequence transitions giving rise to the broad band contour. The calculated free 
$\nu_{\mathrm{NH}}^{\mathrm{f}}$ frequencies of all isomers with a $\mathrm{NH}$ group $\left(>3300 \mathrm{~cm}^{-1}\right.$ for 1-3 and 9-13) appear to be too high to explain the observed hot band transitions contributing to band D, suggesting their absence and/or inefficient photofragmentation resulting from high dissociation thresholds. However, the intense $\nu_{\mathrm{CH}}^{\mathrm{f}}$ modes predicted at $3230 \mathrm{~cm}^{-1}$ for the isomers 4 and 5 are within the experimental absorption range of band $\mathrm{D}$ centered around $3160 \mathrm{~cm}^{-1}$. The difference in frequency $\left(\sim 70 \mathrm{~cm}^{-1}\right)$ can readily by rationalized by anharmonic coupling typical for hot band transitions, which arises from the elevated internal energy of the $\mathrm{C}_{3} \mathrm{H}_{3} \mathrm{~N}^{+}$fragments populating vibrational excited states with high quantum numbers. Such anharmonic coupling (diagonal and off-diagonal) results in red shifts of the transitions compared to the fundamentals predicted by the calculations. Thus, isomers $\mathbf{4}$ and $\mathbf{5}$ are plausible candidates to explain the experimental $\mathrm{C}_{3} \mathrm{H}_{3} \mathrm{~N}^{+}$spectrum despite their relatively high $E_{0}$ values $\left(>100 \mathrm{~kJ} \mathrm{~mol}^{-1}\right)$. Similarly, the intense $\nu_{\mathrm{CH}}^{\mathrm{f}}$ modes of 7 and 8 predicted at 3246 and $3138 \mathrm{~cm}^{-1}$ match the measured IRPD spectrum. The computed $\nu_{\mathrm{CH}}^{\mathrm{f}}$ modes of 6 also lie within the observed spectral range, which suggests that acrylonitrile ${ }^{+}$ could also contribute to the monomer spectrum, although their fundamentals are calculated close to the red edge of transition $\mathrm{D}$ and their IR oscillator strengths are weaker by one order of magnitude than those of the other potential candidates. Thus, from the warm $\mathrm{C}_{3} \mathrm{H}_{3} \mathrm{~N}^{+}$spectrum it is rather difficult to unambiguously determine the dominant contribution of the observed isomers that do not have a NH group. The approach of inert gas tagging discussed in the next section reduces the temperature of the probed ions, and thus increases the spectral resolution of the IRPD spectrum and reduces the effective dissociation threshold, which is required for a more reliable and more definitive identification of the contributing isomers.

\section{3 $\quad \mathrm{C}_{3} \mathrm{H}_{3} \mathrm{~N}^{+}-\mathrm{L}\left(\mathrm{L}=\mathrm{Ar} / \mathrm{N}_{2}\right)$ dimers}

Various $\mathrm{Ar}$ and $\mathrm{N}_{2}$ ligand binding motifs of the $\mathrm{C}_{3} \mathrm{H}_{3} \mathrm{~N}^{+}$monomers identified as potential candidates in Section 4.2 are displayed in Fig. 5 and 6 (along with their IR spectra), while others are presented in Fig. S6 and S7 (ESI $\dagger$ ). The isomers with a $\mathrm{NH}$ group (1-3, 9-13) strongly prefer the formation of a $\mathrm{NH} \cdots \mathrm{L} \mathrm{H}$-bond of $\mathrm{L}$ to the acidic $\mathrm{NH}$ group because of the high partial charge on the NH proton (e.g., $q=0.498 e$ for 1 , Fig. S4, ESI $\dagger$ ). In contrast, in the 4-L and 5-L dimers, the ligand forms a $\mathrm{CH} \cdots \mathrm{L}$ ionic $\mathrm{H}$-bond to the strongly positively charged proton of the terminal $\mathrm{CH}$ group adjacent to $\mathrm{N}(e . g$.,$q=0.718 e$ for 4). For 5-Ar, a $\pi$-bound structure is also calculated, in which the Ar ligand interacts weakly with both the $\mathrm{C} \equiv \mathrm{N} \pi$-cloud and the adjacent $\mathrm{CH}$ group (as evidenced from the NBO calculations, Fig. S8, ESI $\dagger$ ). At this binding site, the Ar ligand has no significant influence on the monomer geometry. Thus, its predicted intense $\nu_{\mathrm{CH}}$ frequency at $3235 \mathrm{~cm}^{-1}$ remains comparable to that of bare 5. A similar $\pi$-bonding motif is also obtained for 6-Ar. However, attempts to optimize such a $\pi$-bound structure with $\mathrm{N}_{2}$ fail because of the strong preference of $\mathrm{N}_{2}$ for $\mathrm{H}$-bonding to acidic $\mathrm{CH} / \mathrm{NH}$ protons over $\pi$-bonding. The $\mathrm{XH} \cdots \mathrm{L}$ ionic $\mathrm{H}$-bonds $\left(\mathrm{X}=\mathrm{N} / \mathrm{C}, \mathrm{L}=\mathrm{Ar} / \mathrm{N}_{2}\right)$ significantly perturb the $\mathrm{XH}$ proton donor groups and leads to an elongation

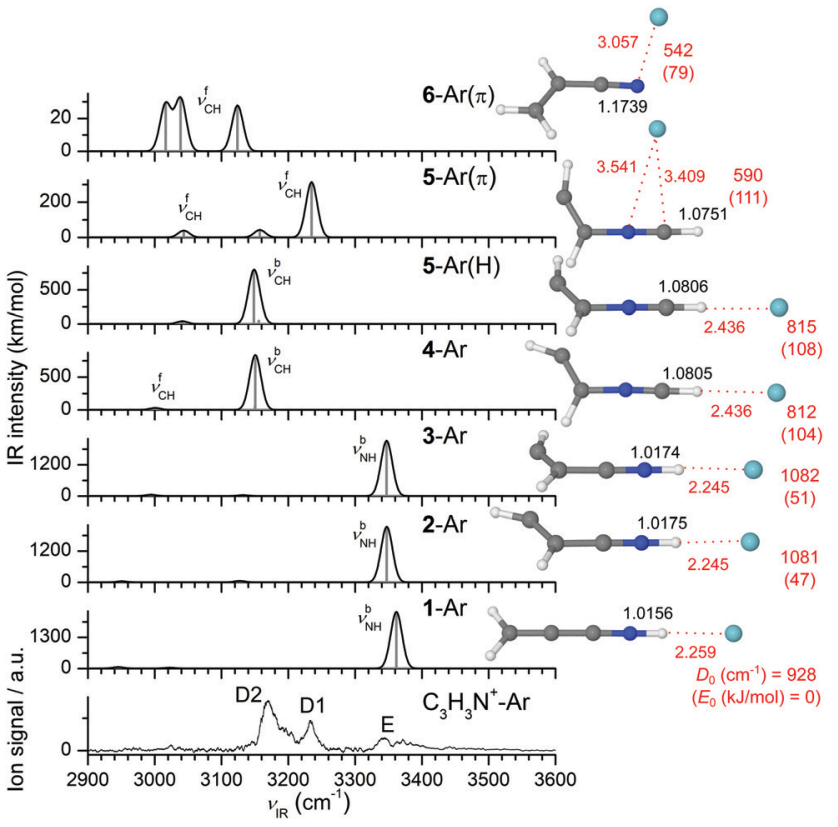

Fig. 5 Comparison of experimental IRPD spectrum of $\mathrm{C}_{3} \mathrm{H}_{3} \mathrm{~N}^{+}-\mathrm{Ar}$ with linear IR absorption spectra of various $\mathrm{C}_{3} \mathrm{H}_{3} \mathrm{~N}^{+}$- $\mathrm{Ar}$ isomers along with the corresponding optimized structures calculated at the B3LYP-D3/aug-ccpVTZ level (Table 2). Binding energies $\left(D_{0}\right)$ and bond lengths are given in $\mathrm{cm}^{-1}$ and $\AA$, respectively. Numbers in parentheses correspond to relative energies in $\mathrm{kJ} \mathrm{mol}^{-1}\left(E_{0}\right)$. A comparison with spectra computed for other $\mathrm{C}_{3} \mathrm{H}_{3} \mathrm{~N}^{+}$-Ar isomers is available in Fig. $\mathrm{S} 6(\mathrm{ESI} \dagger)$.

of the $\mathrm{X}-\mathrm{H}$ bond along with a reduction of the corresponding $\nu_{\mathrm{XH}}^{\mathrm{b}}$ frequency. For the most stable $\mathrm{H}$-bonded 1-Ar/ $\mathrm{N}_{2}$ clusters with a linear $\mathrm{NH} \cdots \mathrm{L} \mathrm{H}$-bond $\left(C_{2 \mathrm{v}}\right)$, the red shift is predicted as $-\Delta \nu_{\mathrm{NH}}=183 / 401 \mathrm{~cm}^{-1}$. The higher proton affinity of $\mathrm{N}_{2}$ as compared to $\operatorname{Ar}\left(\mathrm{PA}=494 \text { vs. } 369 \mathrm{~kJ} \mathrm{~mol}^{-1}\right)^{95}$ causes a larger red shift resulting from the stronger and shorter $\mathrm{NH} \cdots \mathrm{L} \mathrm{H}$-bond $\left(D_{0}=1950\right.$ vs. $928 \mathrm{~cm}^{-1}, R_{\mathrm{NH} \cdots \mathrm{L}}=1.849$ vs. $2.259 \AA$ for $\mathrm{L}=\mathrm{N}_{2}$ and $\mathrm{Ar}$ ). This view is further corroborated by the higher $E^{(2)}$ energy of the $\mathrm{NH} \cdots \mathrm{N}_{2} \mathrm{H}$-bond as compared to the $\mathrm{NH} \cdots \mathrm{Ar}$ bond $\left(E^{(2)}=88.2\right.$ vs. $35.1 \mathrm{~kJ} \mathrm{~mol}^{-1}$, Fig. S8, ESI $\left.\dagger\right)$. The $\mathrm{NH} \cdots \mathrm{L}$ bonds in 2/3-L are similar to those in 1-L, because of their similar $\mathrm{N}-\mathrm{H}$ bond properties. Similar results are also obtained for the $\mathrm{CH} \cdots \mathrm{L} \mathrm{H}$-bonds in $4 / 5-\mathrm{L}(\mathrm{H})$ with $\mathrm{L}=\mathrm{Ar} / \mathrm{N}_{2}$. For these $\mathrm{C}_{3} \mathrm{H}_{3} \mathrm{~N}^{+}$isomers, the Ar ligand again perturbs the $\mathrm{H}$-bonded $\mathrm{CH}$ group less strongly than $\mathrm{N}_{2}$, which results in a smaller $D_{0}$ value for Ar as compared to $\mathrm{N}_{2}\left(e . g ., D_{0}=815 v s .1500 \mathrm{~cm}^{-1}\right.$ for 5) and a longer H-bond $\left(R_{\mathrm{CH} \cdots \mathrm{L}}=2.436\right.$ vs. $\left.2.047 \AA\right)$. As a result, the red shift of the Ar-bound $\nu_{\mathrm{CH}}^{\mathrm{b}}$ mode is smaller than for $\mathrm{N}_{2}$ $\left(-\Delta \nu_{\mathrm{CH}}^{\mathrm{b}}=81\right.$ vs. $\left.176 \mathrm{~cm}^{-1}\right)$. The $E^{(2)}$ values also support this trend $\left(E^{(2)}=26.2\right.$ vs. $\left.52.0 \mathrm{~kJ} \mathrm{~mol}^{-1}\right)$. Analogous results are obtained for the $\mathrm{H}$-bonded 4-L dimers with $\mathrm{L}=\mathrm{Ar} / \mathrm{N}_{2}$. However, in both cases, $4 / 5-\mathrm{L}$, the $\mathrm{CH}$ proton donor group is less strongly perturbed by $\mathrm{H}$-bonding than the more acidic $\mathrm{NH}$ groups in isomers with $\mathrm{NH} \cdots \mathrm{L} \mathrm{H}$-bonds. The relatively low-energy isomers 7/8-Ar $\left(E_{0} \sim 70 \mathrm{~kJ} \mathrm{~mol}^{-1}\right)$ have their intense $\nu_{\mathrm{CH}}^{\mathrm{b}}$ modes at 3211 and $3081 \mathrm{~cm}^{-1}$, respectively, and these frequencies are further red shifted down to 3157 and $3015 \mathrm{~cm}^{-1}$ for the more strongly bonded $\mathrm{N}_{2}$ clusters. As usual, the $\mathrm{N}_{2}$-bound $\mathrm{CH}$ stretch 


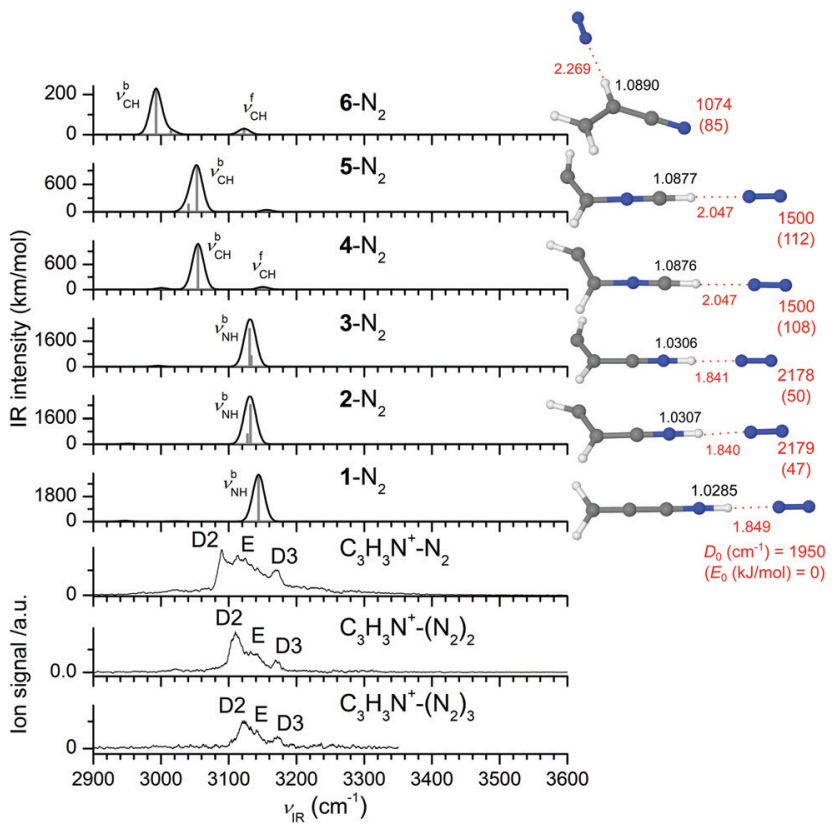

Fig. 6 Comparison of experimental IRPD spectra of $\mathrm{C}_{3} \mathrm{H}_{3} \mathrm{~N}^{+}-\left(\mathrm{N}_{2}\right)_{1-3}$ recorded in the $\mathrm{C}_{3} \mathrm{H}_{3} \mathrm{~N}^{+}$channel with linear $\mathrm{IR}$ absorption spectra of various $\mathrm{C}_{3} \mathrm{H}_{3} \mathrm{~N}^{+}-\mathrm{N}_{2}$ isomers along with the corresponding optimized structures calculated at the B3LYP-D3/aug-cc-pVTZ level (Table 2). Binding energies $\left(D_{0}\right)$ and bond lengths are given in $\mathrm{cm}^{-1}$ and $\AA$, respectively. Numbers in parentheses correspond to relative energies in $\mathrm{kJ} \mathrm{mol}^{-1}\left(E_{0}\right)$. A comparison with spectra computed for other $\mathrm{C}_{3} \mathrm{H}_{3} \mathrm{~N}^{+}-\mathrm{N}_{2}$ isomers is available in Fig. S7 (ESI†).

modes show higher IR intensity because of its larger $\mathrm{H}$-bond affinity than the Ar-bound $\nu_{\mathrm{CH}}^{\mathrm{b}}$ modes reflecting their higher $D_{0}$ value. In general, charge transfer from $\mathrm{C}_{3} \mathrm{H}_{3} \mathrm{~N}^{+}$to the ligands $\mathrm{L}$ is small, as expected for the weak intermolecular $\mathrm{H}$-bonds (e.g., $\Delta q \leq 0.06 e$ for $\mathbf{1} / \mathbf{2} / 4-\mathrm{N}_{2}$, Fig. S4, ESI $\dagger$ ).

Unlike the broad and unresolved $\mathrm{C}_{3} \mathrm{H}_{3} \mathrm{~N}^{+}$monomer spectrum, the $\mathrm{C}_{3} \mathrm{H}_{3} \mathrm{~N}^{+}$-L dimer spectra with both $\mathrm{L}=\mathrm{Ar}$ and $\mathrm{N}_{2}$ exhibit several discernible narrow features because of colder ions. The $\mathrm{C}_{3} \mathrm{H}_{3} \mathrm{~N}^{+}$-Ar spectrum displays three main bands $\mathrm{E}, \mathrm{D} 1$, and $\mathrm{D} 2$ at 3344,3232 , and $3170 \mathrm{~cm}^{-1}$ and is compared in Fig. 5 and Fig. S6 (ESI $\dagger$ ) to spectra computed for potential cluster structures. The satellite bands to the blue of the transitions E and D2 are characteristic of proton donor stretch vibrations involved in H-bonding, ${ }^{30,79,96,97}$ while the rather symmetric band D1 is indicative of a free XH stretch oscillator. Although band $\mathrm{E}$ agrees with the $\nu_{\mathrm{NH}}^{\mathrm{b}}$ mode predicted for the most stable 1-3-Ar(H) dimers (3362 and $3347 \mathrm{~cm}^{-1}$ ), their strong calculated IR intensities $\left(>2000 \mathrm{~km} \mathrm{~mol}^{-1}\right)$ are not reproduced by the measured spectrum. This discrepancy indicates at most a minor contribution of these $\mathrm{C}_{3} \mathrm{H}_{3} \mathrm{~N}^{+}$isomers to the measured spectrum despite their superior stability. The appearance of this band in the spectrum of the Ar-tagged ion reinforces the above hypothesis of inefficient photofragmentation of the bare 1-3 ions that leads to the absence of their $\nu_{\mathrm{NH}}^{\mathrm{f}}$ bands in the monomer spectrum (Section 4.2). This observation illustrates the importance of tagging in order to reduce the fragmentation threshold and to detect all present $\mathrm{C}_{3} \mathrm{H}_{3} \mathrm{~N}^{+}$ isomers (independent of their dissociation threshold). Band D2 is assigned to the intense $\nu_{\mathrm{CH}}^{\mathrm{b}}$ modes of the 4/5-Ar(H) dimers calculated near $3150 \mathrm{~cm}^{-1}$ and band D1 matches the free intense $\nu_{\mathrm{CH}}^{\mathrm{f}}$ mode predicted for the 5- $\operatorname{Ar}(\pi)$ dimer $\left(3235 \mathrm{~cm}^{-1}\right)$. The sequence hot band transitions of band D2 contribute to the intensity of band D1. The remaining free $\nu_{\mathrm{CH}}^{\mathrm{f}}$ modes of $5-\operatorname{Ar}(\pi)$ are not visible in the experimental spectrum due to their weak IR activity. Also, the spectra predicted for the cyclic isomers (9/10-Ar) and 8-Ar agree poorly with the experimental spectrum indicating their absence (or negligible population, Fig. S6, ESI $\dagger$ ). Similarly, the intense $\nu_{\mathrm{CH}}^{\mathrm{b}}$ mode of $\mathrm{H}_{2} \mathrm{CCNCH}^{+}-\mathrm{Ar}$ at $3081 \mathrm{~cm}^{-1}$ disagrees with the measured spectrum. Although the characteristic bound $\nu_{\mathrm{CH}}^{\mathrm{b}}$ mode of $7-\mathrm{Ar}$ at $3211 \mathrm{~cm}^{-1}$ occurs close to transition D1 at $3232 \mathrm{~cm}^{-1}$, its symmetric band contour typical for a free $\mathrm{XH}$ stretch band argues against this interpretation. Furthermore, the predicted $\nu_{\mathrm{NH}}^{\mathrm{b}}$ modes of 11/12-Ar agree to some extent with the band D2. However, because the predicted $\mathbf{1 1} / \mathbf{1 2}-\mathrm{N}_{2}$ spectra fail to explain the measured $\mathrm{C}_{3} \mathrm{H}_{3} \mathrm{~N}^{+}-\mathrm{N}_{2}$ spectrum, we also exclude these isomers from the observed $\mathrm{C}_{3} \mathrm{H}_{3} \mathrm{~N}^{+}$ion population (Fig. S7, ESI $\dagger$ ). There is no indication for the presence of 6-Ar, possibly due to its low Ar binding energy and the low computed IR cross sections. Thus, from the IRPD spectrum of $\mathrm{C}_{3} \mathrm{H}_{3} \mathrm{~N}^{+}$-Ar, we infer a predominant population of $\mathbf{4} / \mathbf{5}$, along with a minor contribution of 1-3. Using the observed intensity ratios of D2 and E $(4: 1)$ and the calculated IR cross sections $(2: 5)$, we can extract a crude estimate of $10: 1$ for the isomer population of $4 / 5$ and 1-3 (assuming similar efficiencies for Ar tagging because of their similar Ar binding energies).

The IRPD spectrum of the $\mathrm{N}_{2}$-tagged dimers shown in Fig. 6 confirms the conclusions drawn from the spectrum of the Ar-tagged $\mathrm{C}_{3} \mathrm{H}_{3} \mathrm{~N}^{+}$ions, namely the predominant population of 4/5 and the minor abundance of 1-3. The $\mathrm{C}_{3} \mathrm{H}_{3} \mathrm{~N}^{+}-\mathrm{N}_{2}$ spectrum also exhibits three main transitions at 3170 (D3), 3118 (E), and 3090 (D2) $\mathrm{cm}^{-1}$, which differ substantially from the $\mathrm{C}_{3} \mathrm{H}_{3} \mathrm{~N}^{+}$-Ar spectrum, because of the stronger $\mathrm{H}$-bonds of $\mathrm{N}_{2}$ causing larger red shifts in the proton-donor stretch modes (Fig. 1). Band E with its satellite bands to the blue is assigned to the $\nu_{\mathrm{NH}}^{\mathrm{b}}$ mode of the most stable $1-3-\mathrm{N}_{2}$ dimer predicted at $3131-3144 \mathrm{~cm}^{-1}$. Its somewhat enhanced IR intensity compared to the Ar spectrum originates from its increased oscillator strength (e.g., $I_{\mathrm{NH}}=3354$ vs. $2370 \mathrm{~km} \mathrm{~mol}^{-1}$ for $1-\mathrm{N}_{2}$ ) resulting from the stronger $\mathrm{NH} \cdots \mathrm{N}_{2} \mathrm{H}$-bond, and the additional contribution of the sequence hot band transitions from the adjacent D2 band. The measured difference of the bands $\mathrm{E}$ (238 $\mathrm{cm}^{-1}$ for 1 -L) agrees well with the difference in the predicted $\nu_{\mathrm{NH}}^{\mathrm{b}}$ bands for the $\mathrm{Ar}$ and $\mathrm{N}_{2}$ clusters $\left(218 \mathrm{~cm}^{-1}\right)$ supporting this assignment. The blueshaded transition D2 is attributed to the $\nu_{\mathrm{CH}}^{\mathrm{b}}$ mode of the $4 / 5-\mathrm{N}_{2}$ isomers calculated near $3055 \mathrm{~cm}^{-1}$, whereas the symmetric D3 transition is attributed to their free $\nu_{\mathrm{CH}}^{\mathrm{f}}$ mode predicted near $3155 \mathrm{~cm}^{-1}$. Again, good agreement between the difference of the bands D $\left(80 \mathrm{~cm}^{-1}\right.$ ) and the predicted $\nu_{\mathrm{NH}}^{\mathrm{b}}$ bands for the $\mathrm{Ar}$ and $\mathrm{N}_{2}$ clusters $\left(96 \mathrm{~cm}^{-1}\right.$ for $\mathbf{1}-\mathrm{N}_{2}$ ) strengthens this assignment. Although the $\mathrm{C}_{3} \mathrm{H}_{3} \mathrm{~N}^{+}-\mathrm{N}_{2}$ spectra computed for the two cyclic $\left(\mathbf{9} / \mathbf{1 3}-\mathrm{N}_{2}\right)$ and $\mathbf{7}-\mathrm{N}_{2}$ isomers fit the experimental spectrum, 
we exclude them because the spectra of their Ar-tagged clusters do not match with the experiment (Fig. S6 and S7, ESI $\dagger$ ). Similarly, we can exclude $\mathbf{8} / \mathbf{1 0} / \mathbf{1 1} / \mathbf{1 2}-\mathrm{N}_{2}$ because of their mismatch with the recorded $\mathrm{N}_{2}$ spectrum. In 6- $\mathrm{N}_{2}$, the $\mathrm{N}_{2}$ ligand prefers H-bonding to the acidic $\mathrm{CH}$ group (while a $\pi$-bonded structure to the $\mathrm{CN}$ group like in $6-\operatorname{Ar}(\pi)$ does not converge to a local minimum), leading to a strong enhancement of the corresponding $\nu_{\mathrm{CH}}^{\mathrm{b}}$ mode, which is however still absent in the IRPD spectrum of $\mathrm{C}_{3} \mathrm{H}_{3} \mathrm{~N}^{+}-\mathrm{N}_{2}$. From this observation, we estimate an upper limit for the abundance of 6 as 30\% from the signal-to-noise ratio $(\sim 45)$ and the IR cross section ratio $(\sim 15)$. To this end, the broad spectrum of the $\mathrm{C}_{3} \mathrm{H}_{3} \mathrm{~N}^{+}$monomer is disentangled by tagging with $\mathrm{Ar}$ and $\mathrm{N}_{2}$, and both cold IRPD spectra can simultaneously be explained only by the presence of the 4/5 (major) and 1-3 (minor) isomers.

\section{$4.4 \mathrm{C}_{3} \mathrm{H}_{3} \mathrm{~N}^{+}-\left(\mathrm{N}_{2}\right)_{n>1}$ clusters}

The IRPD spectra recorded for $\mathrm{C}_{3} \mathrm{H}_{3} \mathrm{~N}^{+}-\left(\mathrm{N}_{2}\right)_{2-3}$ in Fig. 6 further confirm the assignment of the $\mathrm{C}_{3} \mathrm{H}_{3} \mathrm{~N}^{+}$core ions. Efforts to record similar spectra for $\mathrm{C}_{3} \mathrm{H}_{3} \mathrm{~N}^{+}-\mathrm{Ar}_{n \geq 2}$ failed due to inefficient cluster production, probably due to their low binding energy and insufficient cooling of the $\mathrm{C}_{3} \mathrm{H}_{3} \mathrm{~N}^{+}$ions produced by fragmentation of $\mathrm{Pym}^{+}$. No calculations are performed for the $\mathrm{N}_{2}$ clusters with $n \geq 2$. With increasing number of $\mathrm{N}_{2}$ ligands the internal energy of the clusters decreases, which produces higher-resolution spectra with narrower bands. As a result, the shading of the proton-donor bands D2 and E becomes less pronounced and band D3 becomes better resolved. All three transitions D3, E, and D2 observed for $n=1$ show small monotonic blue shifts as $n$ increases to 3 , which is typical for interior ion solvation. ${ }^{30,79,96}$ This noncooperative threebody effect is more pronounced for proton-donor stretch modes involved in $\mathrm{H}$-bonds and relatively small for free $\mathrm{XH}$ stretch oscillators. In addition, the monotonic incremental blueshifts become smaller as the number of ligands increase. As a result, bands D2 and E assigned to bound $\nu_{\mathrm{CH}}^{\mathrm{b}}$ of $4 / 5-\left(\mathrm{N}_{2}\right)_{n}$ and bound $\nu_{\mathrm{NH}}^{\mathrm{b}}$ of 1-3- $\left(\mathrm{N}_{2}\right)_{n}$ show larger incremental shifts $(+20 /+11$ and $+14 /+9 \mathrm{~cm}^{-1}$ for $\left.n=2 / 3\right)$ than D3 assigned to free $\nu_{\mathrm{CH}}^{\mathrm{f}}$ of $4 / 5-\left(\mathrm{N}_{2}\right)_{n}\left(+1 /+1 \mathrm{~cm}^{-1}\right)$. Because the appearance of the $\mathrm{C}_{3} \mathrm{H}_{3} \mathrm{~N}^{+}-\left(\mathrm{N}_{2}\right)_{n}$ spectra is similar for $n=1-3$, the vibrational and isomer assignments are the same. The fact that the IRPD spectrum of $\mathrm{C}_{3} \mathrm{H}_{3} \mathrm{~N}^{+}-\left(\mathrm{N}_{2}\right)_{3}$ is detected in the $\mathrm{C}_{3} \mathrm{H}_{3} \mathrm{~N}^{+}$channel implies that the total binding energy of the three $\mathrm{N}_{2}$ ligands is below the IR photon energy $\left(D_{0}<\nu_{\mathrm{IR}}=2900-3600 \mathrm{~cm}^{-1}\right)$ for all isomers, in line with the computed binding energies for the most strongly bound first $\mathrm{N}_{2}$ ligands.

\section{5 $\quad \mathrm{C}_{2} \mathrm{H}_{2}{ }^{+}-\mathrm{L}$ dimers $\left(\mathrm{L}=\mathrm{Ar} / \mathrm{N}_{2}\right)$}

The $\mathrm{C}_{3} \mathrm{H}_{3} \mathrm{~N}^{+}$ion $(\mathrm{m} / \mathrm{z}$ 53) further dissociates into the lighter $\mathrm{C}_{2} \mathrm{H}_{2}{ }^{+}$ion $(m / z 26)$ by HCN elimination (Fig. S2, ESI $\dagger$ ). We probe the structure of the $\mathrm{C}_{2} \mathrm{H}_{2}{ }^{+}$product ion by IRPD of its $\mathrm{Ar} / \mathrm{N}_{2}$-tagged dimer (Fig. 7), which confirms it as the acetylene cation $\mathrm{HCCH}^{+}\left(\mathrm{H}-\mathrm{C} \equiv \mathrm{C}-\mathrm{H}^{+}\right)$. Out of the two possible $\nu_{\mathrm{CH}}$ normal modes of linear $\mathrm{HCCH}^{+}\left(D_{\infty \mathrm{h}}\right)$ in its ${ }^{2} \Pi_{\mathrm{u}}$ ground electronic state, the symmetric one computed at $\nu_{1}=3225 \mathrm{~cm}^{-1}$ is IR forbidden, while the lower-frequency antisymmetric mode at

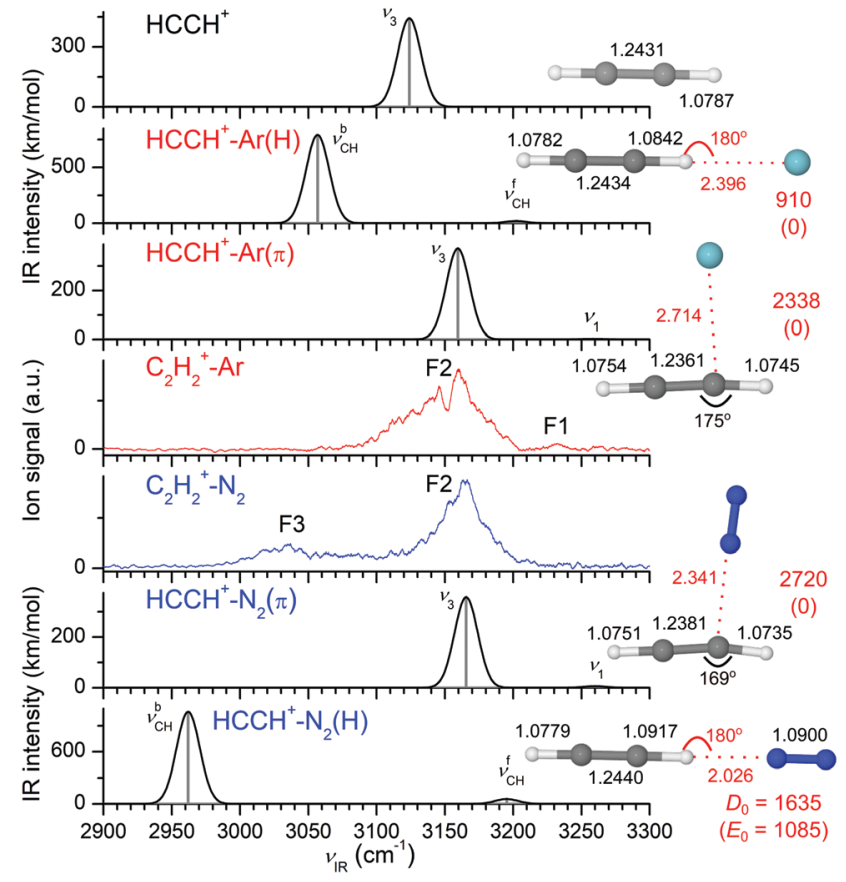

Fig. 7 Comparison of experimental IRPD spectra of $\mathrm{C}_{2} \mathrm{H}_{2}{ }^{+}-\mathrm{Ar} / \mathrm{N}_{2}$ with linear IR absorption spectra of various $\mathrm{HCCH}^{+}-\mathrm{Ar} / \mathrm{N}_{2}$ isomers along with the corresponding optimized structures calculated at the B3LYP-D3/ aug-cc-pVTZ level (Table 3 ). Binding energies $\left(D_{0}\right)$, bond lengths and bond angles are provided in $\mathrm{cm}^{-1}, \AA$ and degrees, respectively. Numbers in parentheses correspond to relative energies in $\mathrm{cm}^{-1}\left(E_{0}\right)$.

$\nu_{3}=3124 \mathrm{~cm}^{-1}$ has high IR activity $\left(I_{\mathrm{CH}}=443 \mathrm{~km} \mathrm{~mol}^{-1}\right)$. Tagging with the inert gas ligand reduces the symmetry which makes the dark $\nu_{1}$ mode weakly IR allowed. The ligand may either form a $\pi$-bond to the $\mathrm{C} \equiv \mathrm{C}$ group, $\mathrm{HCCH}^{+}-\mathrm{L}(\pi)$, or a linear $\mathrm{CH} \cdots \mathrm{L}$ ionic $\mathrm{H}$-bond to one of available $\mathrm{CH}$ groups, $\mathrm{HCCH}^{+}-\mathrm{L}(\mathrm{H})$.

In the more stable $\mathrm{HCCH}^{+}-\mathrm{L}(\pi)$ global minima, the ligand is slightly displaced toward one of the $\mathrm{CH}$ groups, which becomes weakly distorted (Fig. 7 and Table 3). The structure computed for $\mathrm{HCCH}^{+}-\operatorname{Ar}(\pi)$ agrees with previous high level $\operatorname{CCSD}(\mathrm{T})$ calculations. ${ }^{98,99}$ The magnitude of this distortion is stronger for $\mathrm{N}_{2}$ than for Ar because of its higher binding energy $\left(D_{0}=2720\right.$ vs. $\left.2338 \mathrm{~cm}^{-1}\right) \cdot{ }^{72,100}$ The predicted $\nu_{1 / 3}$ modes shift slightly to the blue by $+30 /+41\left(\mathrm{~N}_{2}\right)$ and $+28 /+36 \mathrm{~cm}^{-1}$ (Ar) due to modest charge transfer from $\mathrm{HCCH}^{+}$to $\mathrm{L}$ leading to $\mathrm{C}-\mathrm{H}$ bond contractions $\left(\Delta r_{\mathrm{CH}} \leq-5.2 \mathrm{~m} \AA\right)$. IR activation of $\nu_{1}$ upon $\pi$-bonding is rather minor $\left(I_{\mathrm{CH}}=2 / 6 \mathrm{~km} \mathrm{~mol}^{-1}\right.$ for $\left.\mathrm{Ar} / \mathrm{N}_{2}\right)$. In the less stable linear $\mathrm{HCCH}^{+}-\mathrm{L}(\mathrm{H})$ local minima $\left(D_{0}=910 \mathrm{vs}\right.$. $1635 \mathrm{~cm}^{-1}$ and $R_{\mathrm{CH} \cdots \mathrm{L}}=2.341$ vs. $2.026 \AA$ for $\mathrm{Ar}$ and $\mathrm{N}_{2}$ ) with $C_{\infty \mathrm{v}}$ symmetry, the $\mathrm{CH}$ proton donor group experiences a substantial elongation by H-bonding. As a result, unlike the $\pi$-bound minima, the $\mathrm{CH}$ stretch local modes become largely decoupled. While the free $\nu_{1}\left(\nu_{\mathrm{CH}}^{\mathrm{f}}\right)$ modes at 3202 and $3195 \mathrm{~cm}^{-1}$ for Ar and $\mathrm{N}_{2}$ become weakly IR active $\left(I_{1}=19\right.$ and $\left.57 \mathrm{~km} \mathrm{~mol}^{-1}\right)$, the strongly allowed H-bonded $\nu_{3}\left(\nu_{\mathrm{CH}}^{\mathrm{b}}\right)$ modes at 3057 and $2962 \mathrm{~cm}^{-1}$ are substantially redshifted and further enhanced in IR intensity $\left(I_{3}=791\right.$ vs. $\left.1063 \mathrm{~km} \mathrm{~mol}^{-1}\right)$.

The measured $\mathrm{C}_{2} \mathrm{H}_{2}{ }^{+}$-Ar spectrum reported in Fig. 7 features a strong transition $\mathrm{F} 2$ centered at $3153 \mathrm{~cm}^{-1}$ and a very weak 
band $\mathrm{F} 1$ at $3234 \mathrm{~cm}^{-1}$. Although recorded at lower resolution, this spectrum perfectly reproduces the previously published high-resolution spectrum of $\mathrm{C}_{2} \mathrm{H}_{2}{ }^{+}$-Ar assigned to $\pi$-bound $\mathrm{HCCH}^{+}-\operatorname{Ar}(\pi),{ }^{98}$ as illustrated in Fig. S9 (ESI $\dagger$ ). In the previous studies, ${ }^{98,99} \mathrm{C}_{2} \mathrm{H}_{2}{ }^{+}$-Ar was prepared in a supersonic expansion of acetylene so that it is unambiguous that the $\mathrm{C}_{2} \mathrm{H}_{2}{ }^{+}$ion in the Ar cluster is indeed $\mathrm{HCCH}^{+}$. This is further confirmed by the analysis of the fully rotationally resolved IR spectrum of the $\nu_{3}$ band. ${ }^{98}$ In agreement with the past result, band F2 is assigned to $\nu_{3}$ of $\mathrm{HCCH}^{+}-\operatorname{Ar}(\pi)$ predicted at $3160 \mathrm{~cm}^{-1}$ (and it displays the weakly-resolved Q-branches associated with this vibrational transition, Fig. S9, ESI $\dagger$ ), while the weak band F1 corresponds to $\nu_{1}$ computed at $3258 \mathrm{~cm}^{-1}$. The $\mathrm{C}_{2} \mathrm{H}_{2}{ }^{+}$-Ar spectrum lacks any feature near $3050 \mathrm{~cm}^{-1}$, which indicates the absence of the less stable $\mathrm{HCCH}^{+}-\mathrm{Ar}(\mathrm{H})$ isomer $\left(\nu_{1}=3057 \mathrm{~cm}^{-1}\right)$. The $\mathrm{C}_{2} \mathrm{H}_{2}{ }^{+}-\mathrm{N}_{2}$ spectrum is reported herein for the first time. Its strong transition $\mathrm{F} 2$ at $3165 \mathrm{~cm}^{-1}$ matches the $\nu_{3}$ mode of $\mathrm{HCCH}^{+}$$\mathrm{N}_{2}(\pi)$ calculated at $3166 \mathrm{~cm}^{-1}$. Unlike the Ar case, the two orders of magnitude weaker $\nu_{1}$ mode calculated at $3260 \mathrm{~cm}^{-1}$ is not observed and below the detection limit. Instead, the $\mathrm{C}_{2} \mathrm{H}_{2}{ }^{+}-\mathrm{N}_{2}$ spectrum exhibits a relatively broad transition $\mathrm{F} 3$ peaking near $3035 \mathrm{~cm}^{-1}$, which is assigned to the $\nu_{3}$ mode $\left(\nu_{\mathrm{CH}}^{\mathrm{b}}\right)$ of the less stable $\mathrm{H}$-bonded $\mathrm{HCCH}^{+}-\mathrm{N}_{2}$ dimer predicted at $2962 \mathrm{~cm}^{-1}$. Apparently, the B3LYP-D3 calculations somewhat overestimate the shift for this transition. Our anharmonic calculations reveal that the difference does not result from anharmonicity but from an overestimated force constant. A similar effect is also observed in our unpublished spectra of larger $\mathrm{C}_{2} \mathrm{H}_{2}{ }^{+}-\mathrm{Ar}_{n}$ clusters, in which $\mathrm{Ar}$ ligands start to form $\mathrm{H}$-bonds to $\mathrm{HCCH}^{+}$for cluster sizes $n \geq 3$. Analysis of the observed band intensities along with computed IR cross sections yields a population of $\sim 10 \%$ for the $\mathrm{H}$-bonded local minimum, in line with its smaller binding energy $\left(D_{0}=1635\right.$ vs. $\left.2720 \mathrm{~cm}^{-1}\right)$. We can safely exclude the $\mathrm{H}_{2} \mathrm{CC}^{+}$ion both from energetics ${ }^{101,102}$ and its IR spectrum (Fig. S10, ESI $\dagger$ ).

\subsection{Further discussion}

The $3 \mu \mathrm{m}$ spectra of Pym $^{+}-\left(\mathrm{N}_{2}\right)_{n=1=2}$ provide the first experimental information about the properties of the $\mathrm{C}-\mathrm{H}$ bonds of the radical cation of the fundamental Pym molecule, a basic heterocyclic building block of nucleobases. The $\mathrm{N}_{2}$ ligands prefer $\pi$-bonding at the aromatic ring to H-bonding with the weakly acidic $\mathrm{CH}$ protons. This binding motif hardly influences the $\mathrm{C}-\mathrm{H}$ bond parameters, with very minor changes due to noncooperative effects. Thus, the $\nu_{\mathrm{CH}}$ frequencies of $\mathrm{Pym}^{+}-\mathrm{N}_{2}(\pi)$ and Pym $^{+}-\left(\mathrm{N}_{2}\right)_{2}(\pi / \pi)$ provide an accurate estimate of the four IR active $\nu_{\mathrm{CH}}$ frequencies of bare $\mathrm{Pym}^{+}$as $3124 \pm 2,3112 \pm 2$, $3045 \pm 2$, and $3045 \pm 2 \mathrm{~cm}^{-1}$. These are substantially higher than those measured for neutral Pym (3074, 3050, 3039, and $\left.3002 \mathrm{~cm}^{-1}\right),{ }^{9,88,91}$ indicating that the $\mathrm{C}-\mathrm{H}$ bonds become on average stronger and less acidic upon ionization. Among the $\mathrm{CH}$ groups in $\mathrm{Pym}^{+}$, the acidity increases in the order $\mathrm{C} 2 \mathrm{H}<\mathrm{C} 5 \mathrm{H}<\mathrm{C} 4 \mathrm{H}$, in line with the $\mathrm{C}-\mathrm{H}$ bond lengths and the H-bond energy with $\mathrm{N}_{2}$ (and also HCN). ${ }^{68}$ This is the reason, why a minor population of the observed $\operatorname{Pym}^{+}-\left(\mathrm{N}_{2}\right)_{2}$ cluster cations have a $\mathrm{C} 4 \mathrm{H} \cdots \mathrm{N}_{2}$ ionic $\mathrm{H}$-bond.
Previous information about the interaction of $\mathrm{Pym}^{+}$with nonpolar and polar ligands comes from photoelectron and photoionization spectra of $\mathrm{Pym}^{\mathrm{A}} \mathrm{Ar}_{1 / 2}$ and $\mathrm{Pym}-\mathrm{N}_{2}$ clusters ${ }^{91,103}$ and mass spectrometric studies of $\mathrm{Pym}^{+}-\left(\mathrm{H}_{2} \mathrm{O}\right)_{n}$ clusters. ${ }^{104}$ It was found that $\mathrm{Pym}^{+}-\mathrm{Ar}_{1 / 2}$ clusters have a $(\pi)$ and $(\pi \pi)$ configurations, similar to the structures found here for the most stable structures of Pym- $\left(\mathrm{N}_{2}\right)_{1 / 2}$. No conclusion was presented for the structure of $\mathrm{Pym}^{+}-\mathrm{N}_{2} \cdot{ }^{91}$ The most stable structures computed for $\mathrm{Pym}^{+}-\left(\mathrm{H}_{2} \mathrm{O}\right)_{1-3}$ clusters have linear or bifurcated $\mathrm{CH}$ - O O ionic $\mathrm{H}$-bonds with computed and measured binding energies of $\sim 10 \mathrm{kcal} \mathrm{mol}^{-1}\left(\sim 3500 \mathrm{~cm}^{-1}\right),{ }^{104}$ indicating that the interaction of $\mathrm{Pym}^{+}$with dipolar ligands is not only much stronger than with $\mathrm{N}_{2}$ (because of the additional charge-dipole forces) but also via a different binding motif. Results for the related imidazole ${ }^{+}-\mathrm{N}_{2}$ or pyrrole ${ }^{+}-\mathrm{N}_{2}$ cations show that $\mathrm{N}_{2}$ strongly prefers $\mathrm{H}$-bonding to an acidic $\mathrm{NH}$ group of heterocyclic cations (if available) over $\pi$ or $\mathrm{CH}$ bonding. ${ }^{105,106}$

All previous studies about the primary $\mathrm{C}_{3} \mathrm{H}_{3} \mathrm{~N}^{+}$fragment of $\mathrm{Pym}^{+}$have been based on mass spectrometry, thermochemistry, and quantum chemistry, and no definitive conclusion has been derived about its structure. All probable isomers of the primary $\mathrm{C}_{3} \mathrm{H}_{3} \mathrm{~N}^{+}$fragment of $\mathrm{Pym}^{+}$produced through elimination of $\mathrm{HCN}$ are considered herein to decipher its so far controversial structure by spectroscopy. By comparing the IRPD spectra of the bare hot monomer and its much colder $\mathrm{Ar} / \mathrm{N}_{2}$-tagged clusters, the major contributions of $\mathrm{HCCHNCH}^{+}(c / t)(4 / 5)$ and the minor population of $\mathrm{H}_{2} \mathrm{CCCNH}^{+}$and $\mathrm{HCCHCNH}^{+}(c / t)(1-3)$ are clearly established. In contrast, all other conceivable isomers do not agree with the measured IR spectra and are thus concluded to be below the detection limit. The minor fragment ions, 1-3, are in fact the most stable $\mathrm{C}_{3} \mathrm{H}_{3} \mathrm{~N}^{+}$isomers $\left(E_{0}=0,49,53 \mathrm{~kJ} \mathrm{~mol}^{-1}\right)$, and thus their production may be expected for thermodynamic reasons. On the other hand, the predominant fragment ions, 4/5, are much higher in relative energy $\left(E_{0}=102\right.$ and $\left.107 \mathrm{~kJ} \mathrm{~mol}^{-1}\right)$ but their production is strongly favored for kinetic reasons. They can be formed by simple HCN elimination without any other structural rearrangement. The production of the other isomers at lower energies is strongly hindered by high activation barriers en route from the parent $\mathrm{Pym}^{+}$monomer to the product ions. Although some of the conclusions drawn here have previously been put forward based on mass spectrometry and quantum chemistry, the approach of IR spectroscopy used herein provides for the first time an unequivocal determination of the structures of the detected $\mathrm{C}_{3} \mathrm{H}_{3} \mathrm{~N}^{+}$fragment ions, along with a crude estimate of the branching ratios. Of particular importance has been the tagging approach with weakly bonded inert ligands. First, tagging reduces the temperature leading to higher resolution IR spectra with resolved vibrational structure, which is sufficient to identify all present isomers by their fingerprints. A further effect of tagging is the reduction of the effective dissociation energy, which guarantees that all isomers can be detected by single-photon IRPD, independent of their monomer dissociation energy. This has been vital in the detection of the most stable but minor 1-3 ions. Second, recording IRPD spectra of fragment ions with different tags (here $\mathrm{Ar}$ and $\mathrm{N}_{2}$ ) further increases the selectivity of this spectroscopic 
approach because H-bonding of the tag modifies the IR spectrum depending on its binding affinity, and the identification of the fragment ion should be independent of the tag leading to a multiple test for cases with similar spectra for a single tag. In this way, we can exclude here the isomers 7, 9, and 11-13, because their IRPD spectra fit the IR spectra computed for either the Ar-tagged or $\mathrm{N}_{2}$-tagged clusters but not both of them. Finally, the IR spectra reported for the 4/5 and 1-3 isomers correspond to the first (IR) spectroscopic detection of these radical cations and thus provide a useful probe of the acidity of their $\mathrm{CH}$ and $\mathrm{NH}$ groups and ability to form $\mathrm{H}$-bonds with (nonpolar) ligands.

The $\mathrm{C}_{3} \mathrm{H}_{3} \mathrm{~N}^{+}$ion further disintegrates by elimination of a second $\mathrm{HCN}$ molecule into $\mathrm{C}_{2} \mathrm{H}_{2}^{+}(\mathrm{m} / z$ 26), which was previously established as the acetylene cation $\left(\mathrm{HCCH}^{+}\right)$from thermochemical analysis. We successfully tag this product ion with $\mathrm{Ar}$ and $\mathrm{N}_{2}$, and the resulting IRPD spectra indeed confirm this fragment as $\mathrm{HCCH}^{+}$for the first time by spectroscopic means. The IR spectrum of the alternative high-energy $\mathrm{H}_{2} \mathrm{CC}^{+}$ ion does not match. The $\mathrm{C}_{2} \mathrm{H}_{2}{ }^{+}$-Ar spectrum reproduces the $\mathrm{HCCH}^{+}$-Ar spectrum recorded previously, in which the cluster was prepared in an EI plasma expansion of $\mathrm{HCCH}$. The Ar ligand binds to $\mathrm{HCCH}^{+}$solely through $\pi$-bonding. In contrast, the $\mathrm{HCCH}^{+}-\mathrm{N}_{2}$ spectrum is presented for the first time and reveals also a $\mathrm{H}$-bound local minimum in addition to the $\pi$-bound structure, thus directly probing the acidity of the acetylenic $\mathrm{CH}$ groups. The higher $\mathrm{H}$-bond affinity of $\mathrm{N}_{2}$ is explained by its higher proton affinity compared to $\mathrm{Ar}$ ( $\mathrm{PA}=$ 494 vs. $\left.369 \mathrm{~kJ} \mathrm{~mol}^{-1}\right)^{95}$ leading to a stronger $\mathrm{CH} \cdots \mathrm{L}$ ionic H-bond $\left(D_{0}=1635\right.$ vs. $\left.910 \mathrm{~cm}^{-1}\right)$. However, the population of $\mathrm{HCCH}^{+}-\mathrm{N}_{2}(\mathrm{H})$ is only $\sim 10 \%$ of the $\mathrm{HCCH}^{+}-\mathrm{N}_{2}(\pi)$ global minimum, in line with the computed binding energies.

\section{Conclusions}

We apply herein a combined IR spectroscopic and quantum chemical approach to characterize the structures and bonding of tagged clusters of $\mathrm{Pym}^{+}$and its two most prominent fragment ions, $\mathrm{C}_{3} \mathrm{H}_{3} \mathrm{~N}^{+}$and $\mathrm{C}_{2} \mathrm{H}_{2}{ }^{+}$. The most salient results may be summarized as follows.

The $3 \mu \mathrm{m}$ spectra of $\mathrm{Pym}^{+}-\left(\mathrm{N}_{2}\right)_{n}$ yield the first experimental information about the frequency and thus acidity of the $\mathrm{CH}$ groups of this fundamental building block for nucleobases in its radical cation ground electronic state. In general, removal of the $b_{2}$ electron of Pym results in an overall contraction of the $\mathrm{C}-\mathrm{H}$ bonds, as illustrated by the increase in $\mathrm{CH}$ stretch frequencies upon ionization used as a sensitive probe of the $\mathrm{C}-\mathrm{H}$ bond strength. The $\mathrm{C} 4 \mathrm{H}$ group is the most acidic one and serves as preferred proton donor in $\mathrm{CH} \cdots \mathrm{N}_{2}$ ionic $\mathrm{H}$-bonding. As a result of the reduced acidity of the $\mathrm{CH}$ groups, the inert $\mathrm{N}_{2}$ ligands strongly prefer $\pi$-bonding to the aromatic ring over $\mathrm{H}$-bonding to the $\mathrm{CH}$ groups.

The controversial structures and branching ratios of the primary elusive $\mathrm{C}_{3} \mathrm{H}_{3} \mathrm{~N}^{+}$fragments $(\mathrm{m} / \mathrm{z} 53)$ of $\mathrm{Pym}^{+}$produced by elimination of HCN upon EI are unambiguously identified by spectroscopic means as $\operatorname{HCCHNCH}^{+}(c / t)$ (4/5, major, kinetically favoured) and $\mathrm{H}_{2} \mathrm{CCCNH}^{+} / \mathrm{HCCHCNH}^{+}$(1-3, minor, thermodynamically favoured) by the tagging approach. All other conceivable isomers are below the detection limit. It is demonstrated that the IRPD approach of clusters with different tags is a generally applicable approach for fragment identification, providing high resolution IR spectra with high sensitivity and selectivity. The minor 1-3 fragment ions are the most stable $\mathrm{C}_{3} \mathrm{H}_{3} \mathrm{~N}^{+}$isomers and thus expected from thermochemical arguments. The predominant $\mathbf{4} / \mathbf{5}$ fragment ions are high in energy $\left(E_{0} \sim 100 \mathrm{~kJ} \mathrm{~mol}^{-1}\right)$ but strongly favored by kinetic arguments because they can be formed by simple HCN elimination involving no or low barriers. Clearly, the spectroscopic approach used herein is superior compared to all previous efforts using mass spectrometry, quantum chemistry, and thermochemistry, and provides for the first time an unequivocal determination of the structures of the detected $\mathrm{C}_{3} \mathrm{H}_{3} \mathrm{~N}^{+}$fragment ions, along with a crude estimate of their branching ratio. As a further result, the first IR spectra reported for the 4/5 and 1-3 radical cations provide a direct probe of the acidity of their $\mathrm{C}-\mathrm{H}$ and $\mathrm{N}-\mathrm{H}$ bonds and their ability to form H-bonds with neutral ligands. Finally, the secondary $\mathrm{C}_{2} \mathrm{H}_{2}{ }^{+}$fragment ion $(\mathrm{m} / \mathrm{z} 26)$ resulting from further $\mathrm{HCN}$ loss of $\mathrm{C}_{3} \mathrm{H}_{3} \mathrm{~N}^{+}$is clearly identified as $\mathrm{HCCH}^{+}$ion by spectroscopic means, confirming previous less certain mass spectrometric and thermochemical analysis. While Ar exclusively binds to the $\mathrm{C} \equiv \mathrm{C}$ triple bond, $\mathrm{N}_{2}$ shows some weaker tendency to form a $\mathrm{CH} \cdots \mathrm{N}_{2}$ ionic $\mathrm{H}$-bond, thereby probing the acidity of the $\mathrm{CH}$ groups of the $\mathrm{HCCH}^{+}$radical in its cation ground electronic state. In conclusion, this spectroscopic study provides fundamental characterization of the $\mathrm{Pym}^{+}$precursor and fragment ions of this important biomolecular building block and thus, in the reverse direction, paves the way for understanding the formation of large biomolecules from their smaller building blocks. In general, our spectroscopic results represent a qualitative step forward in the understanding of fragmentation of $\mathrm{Pym}^{+}$and thus provide valuable input into astronomical models simulating the generation of precursor molecules of nucleobases in the interstellar medium. In that sense, it will be further intriguing to spectroscopically investigate similar backbone structures of other biomolecules that play a pivotal role to understand their prebiotic synthesis.

\section{Conflicts of interest}

There are no conflicts to declare.

\section{Acknowledgements}

This study was supported by Deutsche Forschungsgemeinschaft (DFG, project DO 729/3-3).

\section{References}

1 A. Abo-Riziq, L. Grace, E. Nir, M. Kabelac, P. Hobza and M. S. de Vries, Photochemical Selectivity in Guanine-cytosine Basepair Structures, Proc. Natl. Acad. Sci. U. S. A., 2005, 102, 20-23. 
2 A. Broo, A Theoretical Investigation of the Physical Reason for the Very Different Luminescence Properties of the Two Isomers Adenine and 2-Aminopurine, J. Phys. Chem. A, 1998, 102, 526-531.

3 M. S. de Vries and P. Hobza, Gas-Phase Spectroscopy of Biomolecular Building Blocks, Annu. Rev. Phys. Chem., 2007, 58, 585-612.

4 J.-P. Schermann, Spectroscopy and Modeling of Biomolecular Building Blocks, Elsevier, Amsterdam, 2008.

5 T. P. Selvam, C. R. James, P. V. Dniandev and S. K. Valzita, A Mini Review of Pyrimidine and Fused Pyrimidine Marketed Drugs, Res. Pharm., 2015, 2, 01-09.

6 V. Sharma, N. Chitranshi and A. K. Agarwal, Significance and Biological Importance of Pyrimidine in the Microbial World, Int. J. Med. Chem., 2014, 202784.

7 A. K. Jameson and E. C. Lin, Non-radiative decay from photoselected vibrational levels of pyrimidine vapor Franck-Condon effects on $1 \mathrm{p} \pi^{*} \rightarrow 3 \pi \pi^{*}$ intersystem crossing, Chem. Phys. Lett., 1981, 79, 326-330.

8 G. A. Pino, G. Feraud, M. Broquier, G. Grégoire, S. Soorkia, C. Dedonder and C. Jouvet, Non-radiative processes in protonated diazines, pyrimidine bases and an aromatic azine, Phys. Chem. Chem. Phys., 2016, 18, 20126-20134.

9 K. K. Innes, I. G. Ross and W. R. Moomaw, Electronic states of azabenzenes and azanaphthalenes: A revised and extended critical review, J. Mol. Spectrosc., 1988, 132, 492-544.

10 I. Yamazaki, T. Murao, K. Yoshihara, M. Fujita, K. Sushida and $\mathrm{H}$. Baba, Picosecond fluorescence decays from vibrational levels in the $\mathrm{S} 1\left(\mathrm{n}, \pi^{*}\right)$ state of pyridine vapor, Chem. Phys. Lett., 1982, 92, 421-424.

11 D. B. McDonald, G. R. Fleming and S. A. Rice, Intermediate case radiationless decay: the excited state dynamics of pyrazine, Chem. Phys., 1981, 60, 335-345.

12 E. Nir, K. Kleinermanns and M. S. de Vries, Pairing of isolated nucleic-acid bases in the absence of the DNA backbone, Nature, 2000, 408, 949-951.

13 H. Kang, K. T. Lee, B. Jung, Y. J. Ko and S. K. Kim, Intrinsic Lifetimes of the Excited State of DNA and RNA Bases, J. Am. Chem. Soc., 2002, 124, 12958-12959.

14 K. Kleinermanns, D. Nachtigallová and M. S. de Vries, Excited state dynamics of DNA bases, Int. Rev. Phys. Chem., 2013, 32, 308-342.

15 P. R. Callis, Electronic States and Luminescence of Nucleic Acid Systems, Annu. Rev. Phys. Chem., 1983, 34, 329-357.

16 A. Pinchuk, Optical constants and dielectric function of DNA's nucleotides in UV range, J. Quant. Spectrosc. Radiat. Transfer, 2004, 85, 211-215.

17 A. Zalar, D. Tepfer, S. V. Hoffmann, J. M. Kenney and S. Leach, Directed exospermia: I. Biological modes of resistance to UV light are implied through absorption spectroscopy of DNA and potential UV screens, Int. J. Astrobiol., 2007, 6, 229-240.

18 C. E. Crespo-Hernández, B. Cohen, P. M. Hare and B. Kohler, Ultrafast Excited-State Dynamics in Nucleic Acids, Chem. Rev., 2004, 104, 1977-2020.

19 C. Canuel, M. Elhanine, M. Mons, F. Piuzzi, B. Tardivel and I. Dimicoli, Time-resolved photoelectron and photoion fragmentation spectroscopy study of 9-methyladenine and its hydrates: a contribution to the understanding of the ultrafast radiationless decay of excited DNA bases, Phys. Chem. Chem. Phys., 2006, 8, 3978-3987.

20 S. B. Charnley, Y.-J. Kuan, H.-C. Huang, O. Botta, H. M. Butner, N. Cox, D. Despois, P. Ehrenfreund, Z. Kisiel, Y.-Y. Lee, A. J. Markwick, Z. Peeters and S. D. Rodgers, Astronomical searches for nitrogen heterocycles, Adv. Space Res., 2005, 36, 137-145.

21 Y.-J. Kuan, C.-H. Yan, S. B. Charnley, Z. Kisiel, P. Ehrenfreund and H.-C. Huang, A search for interstellar pyrimidine, Mon. Not. R. Astron. Soc., 2003, 345, 650-656.

22 M. N. Simon and M. Simon, Search for Interstellar Acrylonitrile, Pyrimidine, and Pyridine, Astrophys. J., 1973, 184, 757-762.

23 D. M. Hudgins, J. C. W. Bauschlicher and L. J. Allamandola, Variations in the Peak Position of the $6.2 \mu \mathrm{m}$ Interstellar Emission Feature: A Tracer of $\mathrm{N}$ in the Interstellar Polycyclic Aromatic Hydrocarbon Population, Astrophys. J., 2005, 632, 316-332.

24 L. J. Allamandola, A. G. G. M. Tielens and J. R. Barker, Interstellar Polycyclic Aromatic-Hydrocarbons - The Infrared-Emission Bands, The Excitation Emission Mechanism, and The Astrophysical Implications, Astrophys. J., Suppl. Ser., 1989, 71, 733-775.

25 F. Galliano, S. C. Madden, A. G. G. M. Tielens, E. Peeters and A. P. Jones, Variations of the Mid-IR Aromatic Features inside and among Galaxies, Astrophys. J., 2008, 679, 310-345.

26 J. L. Puget and A. Léger, A New Component of the Interstellar Matter: Small Grains and Large Aromatic Molecules, Annu. Rev. Astron. Astrophys., 1989, 27, 161-198.

27 A. G. G. M. Tielens, Interstellar Polycyclic Aromatic Hydrocarbon Molecules, Annu. Rev. Astron. Astrophys., 2008, 46, 289-337.

28 B. A. McGuire, A. M. Burkhardt, S. Kalenskii, C. N. Shingledecker, A. J. Remijan, E. Herbst and M. C. McCarthy, Detection of the Aromatic Molecule Benzonitrile $\left(\mathrm{c}-\mathrm{C}_{6} \mathrm{H}_{5} \mathrm{CN}\right)$ in the Interstellar Medium, Science, 2018, 359, 202-205.

29 C. Joblin and J. Cernicharo, Detecting the building blocks of aromatics, Science, 2018, 359, 156-157.

30 K. Chatterjee and O. Dopfer, Infrared Signatures of Protonated Benzonitrile, Astrophys. J., 2018, 865, 114.

31 K. Chatterjee and O. Dopfer, Switching of binding site from nonpolar to polar ligands toward cationic benzonitrile revealed by infrared spectroscopy, J. Chem. Phys., 2018, 149, 174315.

32 K. Chatterjee and O. Dopfer, Intracluster Proton Transfer in Protonated Benzonitrile- $\left(\mathrm{H}_{2} \mathrm{O}\right)_{n \leq 6}$ Nanoclusters: Hydrated Hydronium Core for $n \geq 2$, Phys. Chem. Chem. Phys., 2019, 21, 25226-25246.

33 R. Hayatsu, Orgueil Meteorite: Organic Nitrogen Contents, Science, 1964, 146, 1291-1293.

34 C. E. Folsome, J. Lawless, M. Romiez and C. Ponnamperuma, Heterocyclic Compounds indigenous to the Murchison Meteorite, Nature, 1971, 232, 108-109.

35 P. G. Stoks and A. W. Schwartz, Uracil in carbonaceous meteorites, Nature, 1979, 282, 709-710. 
36 M. P. Callahan, K. E. Smith, H. J. Cleaves, J. Ruzicka, J. C. Stern, D. P. Glavin, C. H. House and J. P. Dworkin, Carbonaceous meteorites contain a wide range of extraterrestrial nucleobases, Proc. Natl. Acad. Sci. U. S. A., 2011, 108, 13995-13998.

37 R. Shapiro, Prebiotic cytosine synthesis: A critical analysis and implications for the origin of life, Proc. Natl. Acad. Sci. U. S. A., 1999, 96, 4396-4401.

38 A. W. Schwartz and G. J. F. Chittenden, Synthesis of uracil and thymine under simulated prebiotic conditions, BioSystems, 1977, 9, 87-92.

39 B. Basile, A. Lazcano and J. Oró, Prebiotic syntheses of purines and pyrimidines, Adv. Space Res., 1984, 4, 125-131.

40 C. K. Materese, M. Nuevo, P. P. Bera, T. J. Lee and S. A. Sandford, Thymine and Other Prebiotic Molecules Produced from the Ultraviolet Photo-Irradiation of Pyrimidine in Simple Astrophysical Ice Analogs, Astrobiology, 2013, 13, 948-962.

41 C. K. Materese, M. Nuevo, B. L. McDowell, C. E. Buffo and S. A. Sandford, The Photochemistry of Purine in Ice Analogs Relevant to Dense Interstellar Clouds, Astrophys. J., 2018, 864, 44.

42 Y. Oba, Y. Takano, H. Naraoka, N. Watanabe and A. Kouchi, Nucleobase synthesis in interstellar ices, Nat. Commun., 2019, 10, 4413.

43 R. Glaser, B. Hodgen, D. Farrelly and E. McKee, Adenine Synthesis in Interstellar Space: Mechanisms of Prebiotic Pyrimidine-Ring Formation of Monocyclic HCN-Pentamers, Astrobiology, 2007, 7, 455-470.

44 M. Nuevo, S. N. Milam and S. A. Sandford, Nucleobases and Prebiotic Molecules in Organic Residues Produced from the Ultraviolet Photo-Irradiation of Pyrimidine in $\mathrm{NH}_{3}$ and $\mathrm{H}_{2} \mathrm{O}+\mathrm{NH}_{3}$ Ices, Astrobiology, 2012, 12, 295-314.

45 M. Nuevo, S. N. Milam, S. A. Sandford, J. E. Elsila and J. P. Dworkin, Formation of Uracil from the Ultraviolet Photo-Irradiation of Pyrimidine in Pure $\mathrm{H}_{2} \mathrm{O}$ Ices, Astrobiology, 2009, 9, 683-695.

46 P. P. Bera, M. Nuevo, S. N. Milam, S. A. Sandford and T. J. Lee, Mechanism for the abiotic synthesis of uracil via UV-induced oxidation of pyrimidine in pure $\mathrm{H}_{2} \mathrm{O}$ ices under astrophysical conditions, J. Chem. Phys., 2010, 133, 104303.

47 C. K. Materese, M. Nuevo and S. A. Sandford, The Formation of Nucleobases from the Ultraviolet Photoirradiation of Purine in Simple Astrophysical Ice Analogues, Astrobiology, 2017, 17, 761-770.

48 M. P. Robertson and G. F. Joyce, The Origins of the RNA World, Cold Spring Harbor Perspect. Biol., 2012, 4, a003608.

49 Z. Yang, P. Duffy and F. Wang, Inheritance and correlation of nucleic acid pyrimidine bases, Int. J. Quantum Chem., 2013, 113, 2312-2318.

50 F. Wang and Q. Zhu, Inner-shell chemical shift of DNA/ RNA bases and inheritance from their parent purine and pyrimidine, J. Synchrotron Radiat., 2008, 15, 624-631.

51 I. Linert, M. Dampc, B. Mielewska and M. Zubek, Cross sections for ionization and ionic fragmentation of pyrimidine molecules by electron collisions, Eur. Phys. J. D, 2012, 66, 20.

52 H. Abdoul-Carime and L. Sanche, Fragmentation of short single DNA strands by 1-30 eV electrons: dependence on base identity and sequence, Int. J. Radiat. Biol., 2002, 78, 89-99.

53 J. E. Elsila, M. R. Hammond, M. P. Bernstein, S. A. Sandford and R. N. Zare, UV photolysis of quinoline in interstellar ice analogs, Meteorit. Planet. Sci., 2006, 41, 785-796.

$54 \mathrm{H}$. Ichikawa and M. Ogata, Molecular orbital approach to the interpretation of organic mass spectra. III. Determination of intermediate ion structure in the mass spectrometry of heteroaromatic compounds, J. Am. Chem. Soc., 1973, 95, 806-811.

55 J. M. Rice, G. O. Dudek and M. Barber, Mass Spectra of Nucleic Acid Derivatives. Pyrimidines, J. Am. Chem. Soc., 1965, 87, 4569-4576.

56 R. Buff and J. Dannacher, The least endothermic fragmentation pathways of the diazine cations, Int. J. Mass Spectrom. Ion Processes, 1984, 62, 1-15.

57 M. Schwell, H.-W. Jochims, H. Baumgärtel and S. Leach, VUV photophysics and dissociative photoionization of pyrimidine, purine, imidazole and benzimidazole in the 7-18 eV photon energy range, Chem. Phys., 2008, 353, 145-162.

58 H. K. Ervasti, K. J. Jobst, P. Gerbaux, P. C. Burgers, P. J. A. Ruttink and J. K. Terlouw, The reaction of the acrylonitrile ion $\mathrm{CH}_{2} \mathrm{CH}-\mathrm{CN}^{+}$with $\mathrm{HCN}$ : Proton-transport catalysis vs. formation of ionized pyrimidine, Chem. Phys. Lett., 2009, 482, 211-216.

59 O. Plekan, M. Coreno, V. Feyer, A. Moise, R. Richter, M. D. Simone, R. Sankari and K. C. Prince, Electronic state resolved PEPICO spectroscopy of pyrimidine, Phys. Scr., 2008, 78, 058105.

60 F. Milani-nejad and H. D. Stidham, Spectra of C2v deuterium substituted pyrimidines, Spectrochim. Acta, Part A, 1975, 31, 1433-1453.

61 K. J. Jobst, S. A. Hasan and J. K. Terlouw, Does the Ionmolecule Reaction between $\mathrm{HCCH}^{+}$and $\mathrm{HCN}$ Lead to $\mathrm{CH}_{2} \mathrm{CH}-\mathrm{CN}^{+}$? A Computational and Experimental Study of the Reverse Process, Chem. Phys. Lett., 2008, 450, 243-247.

62 N. Takagi, K. Fukuzawa, Y. Osamura and H. F. Schaefer, Ion-molecule Reactions Producing $\mathrm{HC}_{3} \mathrm{NH}^{+}$in Interstellar Space: Forbiddenness of the Reaction between Cyclic $\mathrm{C}_{3} \mathrm{H}_{3}{ }^{+}$and the N Atom, Astrophys. J., 1999, 525, 791-798.

63 J. G. Philis, The Multiphoton Ionization Spectrum of Jetcooled Pyrimidine in the $3 p$ Rydberg and ${ }^{3} \mathrm{~B}_{1}(\pi, n)$ States, J. Mol. Spectrosc., 2005, 232, 26-29.

64 D. J. Lavorato, T. K. Dargel, W. Koch, G. A. McGibbon, H. Schwarz and J. K. Terlouw, Pyrimidine-ylidenes Produced using Neutralization-reionization Mass Spectrometry and Probed by Density Functional Methods, Int. J. Mass Spectrom., 2001, 210-211, 43-57.

65 L. D. Fondren, J. McLain, D. M. Jackson, N. G. Adams and L. M. Babcock, Studies of reactions of a series of ions with 
nitrogen containing heterocyclic molecules using a selected ion flow tube, Int. J. Mass Spectrom., 2007, 265, 60-67.

66 S. Petrie, C. G. Freeman and M. J. McEwan, The ion-molecule chemistry of acrylonitrile: astrochemical implications, Mon. Not. R. Astron. Soc., 1992, 257, 438-444.

67 P. P. Bera, T. J. Lee and H. F. Schaefer, Are Isomers of the Vinyl Cyanide Ion Missing Links for Interstellar Pyrimidine Formation?, J. Chem. Phys., 2009, 131, 074303.

68 A. M. Hamid, P. P. Bera, T. J. Lee, S. G. Aziz, A. O. Alyoubi and M. S. El-Shall, Evidence for the Formation of Pyrimidine Cations from the Sequential Reactions of Hydrogen Cyanide with the Acetylene Radical Cation, J. Phys. Chem. Lett., 2014, 5, 3392-3398.

69 G. Vall-llosera, M. Coreno, P. Erman, M. A. Huels, K. Jakubowska, A. Kivimäki, E. Rachlew and M. Stankiewicz, VUV photoionisation of free azabenzenes: Pyridine, pyrazine, pyrimidine, pyridazine and s-triazine, Int. J. Mass Spectrom., 2008, 275, 55-63.

70 N. Solcà and O. Dopfer, Protonated Benzene: IR Spectrum and Structure of $\mathrm{C}_{6} \mathrm{H}_{7}^{+}$, Angew. Chem., Int. Ed., 2002, 41, 3628-3631.

71 A. Patzer, S. Chakraborty, N. Solcà and O. Dopfer, IR Spectrum and Structure of the Phenyl Cation, Angew. Chem., Int. Ed., 2010, 49, 10145-10148.

72 H.-S. Andrei, N. Solcà and O. Dopfer, IR Spectrum of the Ethyl Cation: Evidence for the Nonclassical Structure, Angew. Chem., Int. Ed., 2008, 47, 395-397.

73 A. Patzer, M. Schütz, T. Möller and O. Dopfer, Infrared Spectrum and Structure of the Adamantane Cation: Direct Evidence for Jahn-Teller Distortion, Angew. Chem., Int. Ed., 2012, 51, 4925-4929.

74 K. Chatterjee, O. Dopfer, K. Chatterjee and O. Dopfer, Microhydration of $\mathrm{PAH}^{+}$Cations: Evolution of Hydration Network in Naphthalene ${ }^{+}-\left(\mathrm{H}_{2} \mathrm{O}\right)_{n}$ clusters $(n \leq 5)$, Chem. Sci., 2018, 9, 2301-2318.

75 K. Chatterjee and O. Dopfer, Protonation of Naphthalene$(\text { Water })_{n}$ Nanoclusters: Intracluster Proton Transfer to Hydration Shell Revealed by Infrared Photodissociation Spectroscopy, J. Phys. Chem. A, 2020, 124, 1134-1151.

76 K. Chatterjee and O. Dopfer, Microhydration Structures of Protonated Oxazole, J. Phys. Chem. A, 2019, 123, 7637-7650.

77 K. Chatterjee, Y. Matsumoto and O. Dopfer, Aromatic Charge Resonance Interaction Probed by Infrared Spectroscopy, Angew. Chem., Int. Ed., 2019, 58, 3351-3355.

78 O. Dopfer, Spectroscopic and Theoretical studies of $\mathrm{CH}_{3}{ }^{+}-\mathrm{Rg}_{n}$ clusters $(\mathrm{Rg}=\mathrm{He}, \mathrm{Ne}, \mathrm{Ar})$ : From weak intermolecular forces to chemical reaction mechanisms, Int. Rev. Phys. Chem., 2003, 22, 437-495.

79 O. Dopfer, IR Spectroscopy of Microsolvated Aromatic Cluster Ions: Ionization-Induced Switch in Aromatic Molecule-Solvent Recognition, Z. Phys. Chem., 2005, 219, 125.

80 P. J. Linstrom and W. G. Mallard, NIST Chemistry WebBook, NIST Standards and Technology, Gaithersburg MD, 2017, p. 20899, http://webbook.nist.gov.

81 M. J. Frisch, et al., Gaussian 09, version D.01, Gaussian, Inc, Wallingford, CT, 2009.
82 E. D. Glendening, J. K. Badenhoop, A. E. Reed, J. E. Carpenter, J. A. Bohmann, C. M. Morales, C. R. Landis and F. Weinhold, NBO 6.0, Theoretical Chemistry, University of Wisconsin, Madison, 2013.

83 L. Fernholt and C. Romming, Molecular-structure of Gaseous Pyrimidine, Acta Chem. Scand., 1978, 32, 271-273.

84 S. Albert and M. Quack, High resolution rovibrational spectroscopy of pyrimidine: Analysis of the B1 modes $\nu_{10 \mathrm{~b}}$ and $\nu_{4}$ and B2 mode $\nu_{6 \mathrm{~b}}$, J. Mol. Spectrosc., 2007, 243, 280-291.

85 S. Breda, I. D. Reva, L. Lapinski, M. J. Nowak and R. Fausto, Infrared spectra of pyrazine, pyrimidine and pyridazine in solid argon, J. Mol. Struct., 2006, 786, 193-206.

86 R. C. Lord, A. L. Marston and F. A. Miller, Infra-red and Raman spectra ot the diazines, Spectrochim. Acta, 1957, 9, 113-125.

87 Z. N. Heim, B. K. Amberger, B. J. Esselman, J. F. Stanton, R. C. Woods and R. J. McMahon, Molecular Structure Determination: Equilibrium Structure of Pyrimidine $\left(\mathrm{m}-\mathrm{C}_{4} \mathrm{H}_{4} \mathrm{~N}_{2}\right)$ from Rotational Spectroscopy $\left(r_{\mathrm{e}}^{\mathrm{SE}}\right)$ and Highlevel ab initio Calculation $\left(r_{\mathrm{e}}\right)$ Agree within the Uncertainty of Experimental Measurement, J. Chem. Phys., 2020, 152, 104303.

88 L. Bokobza-Sebagh and J. Zarembowitch, Apport de la coordination des hétérocycles à la connaisance de leurs spectres i.r. Raman-II. spectres de la pyrimidine, Spectrochim. Acta, Part A, 1976, 32, 797-805.

89 R. Gleiter, E. Heilbronner and V. Hornung, Photoelectron Spectra of Azabenzenes and Azanaphthalenes: I. Pyridine, diazines, s-triazine and s-tetrazine, Helv. Chim. Acta, 1972, 55, 255-274.

90 A. W. Potts, D. M. P. Holland, A. B. Trofimov, J. Schirmer, L. Karlsson and K. Siegbahn, An experimental and theoretical study of the valence shell photoelectron spectra of purine and pyrimidine molecules, J. Phys. B: At., Mol. Opt. Phys., 2003, 36, 3129-3143.

91 S. Sato, K. Omiya and K. Kimura, Cation vibrational spectra of pyrimidine and its van der Waals complexes with $\mathrm{Ar}$ and $\mathrm{N}_{2}$ by ZEKE photoelectron spectroscopy, J. Electron Spectrosc. Relat. Phenom., 1998, 97, 121-129.

92 J. H. Kim, J. H. Lee, H. Hwang, H. L. Kim and C. H. Kwon, Determination of precise pyrimidine cationic structure by vacuum ultraviolet mass-analyzed threshold ionization spectroscopy, Phys. Chem. Chem. Phys., 2014, 16, 1590-1596.

93 M. Riese and J. Grotemeyer, Mass-analyzed threshold ionization spectroscopy of pyrimidine: determining the geometry in the first excited and the ionic ground states, Anal. Bioanal. Chem., 2006, 386, 59-68.

94 K. Elkner, R. C. Binning Jr and D. E. Bacelo, Structures and G3X energies of $\mathrm{C}_{3} \mathrm{H}_{3} \mathrm{~N}^{+}$intermediates, Int. J. Quantum Chem., 2006, 106, 3043-3047.

95 E. P. L. Hunter and S. G. Lias, Evaluated Gas Phase Basicities and Proton Affinities of Molecules: An Update, J. Phys. Chem. Ref. Data, 1998, 27, 413-656.

96 N. Solcà and O. Dopfer, Microsolvation of the Phenol Cation $\left(\mathrm{Ph}^{+}\right)$in Nonpolar Environments: Infrared Spectra 
of $\mathrm{Ph}^{+}-\mathrm{L}_{n}\left(\mathrm{~L}=\mathrm{He}, \mathrm{Ne}, \mathrm{Ar}, \mathrm{N}_{2}, \mathrm{CH}_{4}\right)$, J. Phys. Chem. A, 2001, 105, 5637-5645.

97 R. V. Olkhov and O. Dopfer, Spectroscopic and ab initio studies of ionic hydrogen bonds: the $\mathrm{O}-\mathrm{H}$ stretch vibration of $\mathrm{SiOH}^{+}-\mathrm{X}$ dimers $\left(\mathrm{X}=\mathrm{He}, \mathrm{Ne}, \mathrm{Ar}, \mathrm{N}_{2}\right)$, Chem. Phys. Lett., 1999, 314, 215-222.

98 O. Dopfer, R. V. Olkhov, M. Mladenović and P. Botschwina, Intermolecular Interaction in an Open-shell $\pi$-bound Cationic Complex: IR Spectrum and Coupled Cluster Calculations for $\mathrm{C}_{2} \mathrm{H}_{2}{ }^{+}$-Ar, J. Chem. Phys., 2004, 121, 1744-1753.

99 R. A. Relph, J. C. Bopp, J. R. Roscioli and M. A. Johnson, Structural Characterization of $\left(\mathrm{C}_{2} \mathrm{H}_{2}\right)_{1-6}{ }^{+}$Cluster Ions by Vibrational Predissociation Spectroscopy, J. Chem. Phys., 2009, 131, 114305.

100 O. Dopfer, H.-S. Andrei and N. Solcà, IR Spectra of $\mathrm{C}_{2} \mathrm{H}_{5}{ }^{+}-\mathrm{N}_{2}$ Isomers: Evidence for Dative Chemical Bonding in the Isolated Ethanediazonium Ion, J. Phys. Chem. A, 2011, 115, 11466-11477.

101 J. Baker, On the Stability of the Vinylidene Radical Cation, Chem. Phys. Lett., 1989, 159, 447-451.
102 S. Boyé-Péronne, D. Gauyacq and J. Liévin, Vinylideneacetylene cation isomerization investigated by large scale ab initio calculations, J. Chem. Phys., 2006, 124, 214305.

103 H. Abe, Y. Ohyanagi, M. Ichijo, N. Mikami and M. Ito, Vibrational predissociation and nonradiative process of electronically excited van der Waals complexes of pyrimidine, J. Phys. Chem., 1985, 89, 3512-3521.

104 A. M. Hamid, P. Sharma, M. Samy El-Shall, R. Hilal, S. Elroby, S. G. Aziz and A. O. Alyoubi, Hydration of the Pyrimidine Radical Cation and Stepwise Solvation of Protonated Pyrimidine with Water, Methanol, and Acetonitrile, J. Chem. Phys., 2013, 139, 084304.

105 H.-S. Andrei, N. Solcà and O. Dopfer, Interaction of Ionic Biomolecular Building Blocks with Nonpolar Solvents: Acidity of the Imidazole Cation $\left(\mathrm{Im}^{+}\right)$Probed by IR Spectra of $\mathrm{Im}^{+}-\mathrm{L}_{n}$ Complexes $\left(\mathrm{L}=\mathrm{Ar}, \mathrm{N}_{2} ; n \leq 3\right)$, J. Phys. Chem. A, 2005, 109, 3598-3607.

106 M. Schütz, Y. Matsumoto, A. Bouchet, M. Öztürk and O. Dopfer, Microsolvation of the Pyrrole Cation $\left(\mathrm{Py}^{+}\right)$with Nonpolar and Polar Ligands: Infrared Spectra of $\mathrm{Py}^{+}-\mathrm{L}_{n}$ with $\mathrm{L}=\mathrm{Ar}, \mathrm{N}_{2}$, and $\mathrm{H}_{2} \mathrm{O}(n \leq 3)$, Phys. Chem. Chem. Phys., 2017, 19, 3970-3986. 